\title{
Solvent-Controlled Selective Transformation of 2-Bromomethyl-2- methylaziridines to Functionalized Aziridines and Azetidines
}

\author{
Sonja Stanković, ${ }^{\dagger}$ Hannelore Goossens, ${ }^{\ddagger}$ Saron Catak, ${ }^{\dagger}$ Meniz Tezcan, ${ }^{\dagger}$ Michel Waroquier, ${ }^{\ddagger}$ \\ Veronique Van Speybroeck, ${ }^{*+}$ Matthias D’hooghe, ${ }^{* \dagger}$ and Norbert De Kimpe ${ }^{* \dagger}$ \\ ${ }^{\dagger}$ Department of Sustainable Organic Chemistry and Technology, Faculty of Bioscience Engineering, Ghent University, Coupure Links \\ 653, B-9000 Ghent, Belgium \\ ${ }^{\ddagger}$ Center for Molecular Modeling, Ghent University, Technologiepark 903, B-9052 Zwijnaarde, Belgium, Member of QCMM-Alliance \\ Ghent-Brussels
}

Supporting Information

ABSTRACT: The reactivity of 2-bromomethyl-2-methylaziridines toward oxygen, sulfur, and carbon nucleophiles in different solvent systems was investigated. Remarkably, the choice of the solvent has a profound influence on the reaction outcome, enabling the selective formation of either functionalized aziridines in dimethylformamide (through direct bromide displacement) or azetidines in acetonitrile (through rearrangement via a bicyclic aziridinium intermediate). In addition, the experimentally observed solvent-dependent behavior of 2 bromomethyl-2-methylaziridines was further supported by means of DFT calculations.

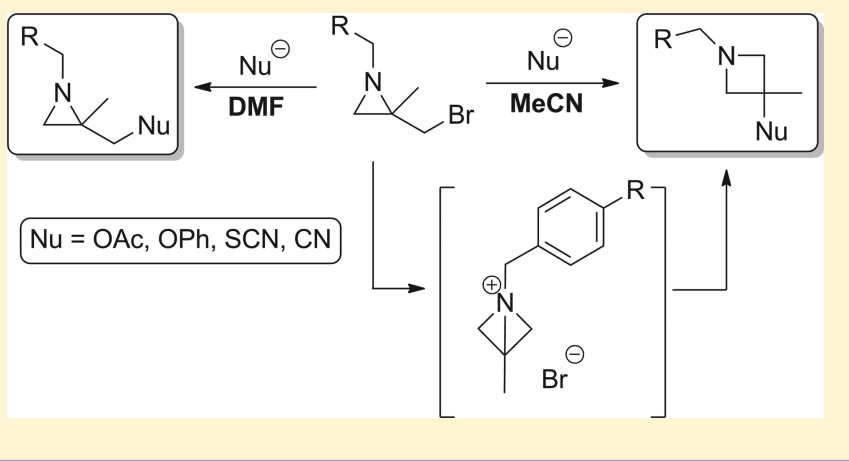

Scheme 1. Reactivity of 1-Alkyl-2-(bromomethyl)aziridines 1 with Respect to $\mathrm{NaBH}_{4}$ in $\mathrm{MeOH}$
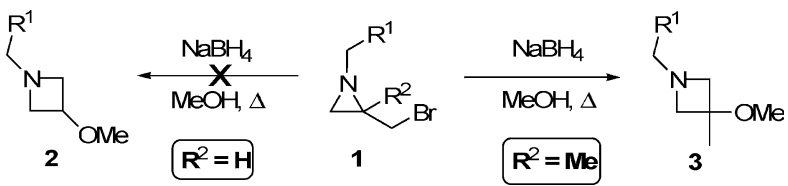

other hand, we recently reported that structurally similar 2bromomethyl-2-methylaziridines $\mathbf{1}\left(\mathrm{R}^{2}=\mathrm{Me}\right)$ readily rearrange into 3-methoxy-3-methylazetidines 3 under the same reaction conditions $\left(\mathrm{NaBH}_{4}, \mathrm{MeOH}\right.$, reflux $){ }^{16}$ In the same paper, a single example of the ring rearrangement of a 2-bromomethyl2-methylaziridine into the corresponding 3-bromo-3-methylazetidine has been described as well upon heating in acetonitrile for $15 \mathrm{~h}$. The isomerization of 2-(halomethyl)aziridines to 3haloazetidines has been observed in the literature in only a few exceptional cases, ${ }^{17}$ pointing to the peculiar nature of this type of rearrangement.

The limited number of reports regarding aziridine to azetidine ring expansions and the mainly unexplored synthetic potential of 2-bromomethyl-2-methylaziridines prompted us to investigate the chemistry of this class of aziridines in more detail. Thus, the present study deals with the reactivity of 2bromomethyl-2-methylaziridines $\mathbf{1}\left(\mathrm{R}^{2}=\mathrm{Me}\right)$ toward different oxygen, sulfur and carbon nucleophiles in different solvent

Received: December 21, 2011

Published: February 21, 2012 
systems, providing an unexpected solvent-mediated synthesis of substituted aziridines and azetidines selectively. The experimentally observed results were further investigated and supported by high-level molecular modeling.

\section{RESULTS AND DISCUSSION}

Experimental Results. The synthesis of 2-bromomethyl-2methylaziridines 4 through $\mathrm{NaBH}_{4}$-mediated reduction of $\alpha, \beta$ dibromoaldimines, obtained by bromination and subsequent imination of 2-methylpropenal, has recently been reported. ${ }^{16}$ To provide a general access to novel 3-bromoazetidines as versatile synthons, 2-bromomethyl-2-methylaziridines $4 \mathbf{a}-\mathbf{c}$ were subjected to heating in acetonitrile at reflux temperature for $15 \mathrm{~h}$. These reactions resulted in the selective formation of 3-bromo-3-methylazetidines $6 \mathrm{a}-\mathrm{c}$, obtained through bromide attack at the more-hindered carbon atom of the intermediate bicyclic aziridinium species 5 (Scheme 2). The broad synthetic

Scheme 2. Transformation of 2-(Bromomethyl)aziridines 4 to 3-Bromoazetidines $6 \mathrm{a}-\mathrm{c}$

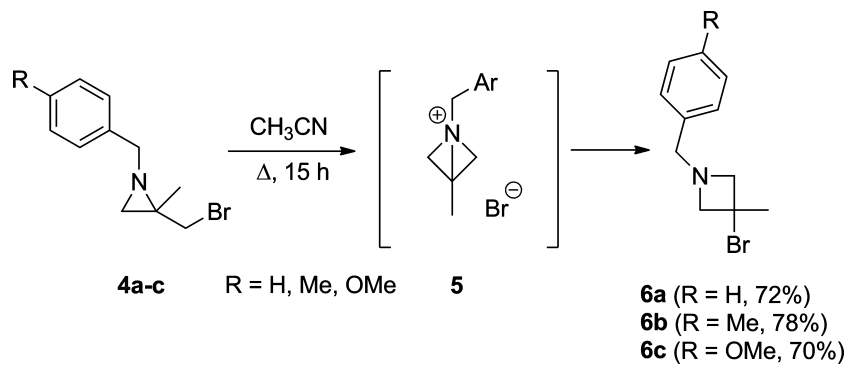

potential of 3-haloazetidines has been demonstrated in the literature in terms of their nucleophilic substitution with different nucleophiles. ${ }^{18}$ The intermediacy of bicyclic aziridinium species $\mathbf{5}$ in this peculiar aziridine to azetidine rearrangement protocol has previously been studied and was confirmed by means of high level molecular modeling calculations. ${ }^{16}$ It should be stressed that this thermodynamically-controlled aziridine to azetidine rearrangement has very few precedents in the chemical literature and might provide a window of opportunities for the selective synthesis of novel 3substituted azetidines.

Thus, the intrinsic reactivity of 2-bromomethyl-2-methylaziridines 4 to undergo a ring rearrangement was further investigated utilizing a variety of different nucleophiles such as thiocyanate, cyanide, phenoxide and acetate to assess the scope of this transformation with respect to carbon and heteroatom nucleophiles.

First, aziridines $\mathbf{4 a}-\mathbf{c}$ were treated with 1 equiv of $\mathrm{KSCN}$ in acetonitrile at reflux temperature for $2-4 \mathrm{~h}$, furnishing mixtures of 3-methyl-3-thiocyanatoazetidines $7 \mathbf{a}-\mathbf{c}$ and 2-methyl-2(thiocyanatomethyl)aziridines $\mathbf{8 a}-\mathbf{c}$, with azetidines $7 \mathbf{a}-\mathbf{c}$ being the major products (ratio $7 / 8=50-67 / 50-33$, entry 1-3, Table 1) (Scheme 3). From these mixtures, azetidines

Scheme 3. Transformation of 2-Bromomethyl-2methylaziridines 4 to Functionalized Azetidines 7 and Aziridines 8

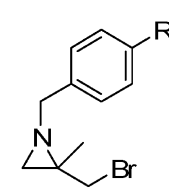

$4 a(R=H)$

$4 \mathbf{b}(\mathrm{R}=\mathrm{Me})$

$4 c(R=O M e)$
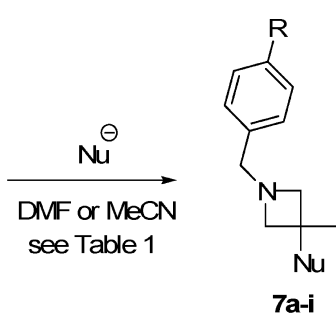

7a-i see Table 1

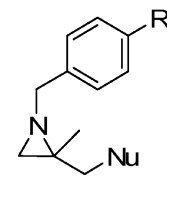

8a-i
$7 \mathbf{a}-\mathbf{c}$ were isolated in pure form by preparative TLC chromatography on silica gel. Several experiments were performed to optimize the reaction conditions. Surprisingly, when aziridines $4 a-c$ were treated with 1 equiv of KSCN in DMF at $60-70{ }^{\circ} \mathrm{C}$ for $15-20 \mathrm{~h}$ aziridines $8 \mathrm{a}-\mathrm{c}$ were obtained as the sole reaction products (entry $10-12$, Table 1 ), giving rise to a new and straightforward synthetic methodology for the selective preparation of either aziridines in DMF and azetidines in acetonitrile. Aziridines 8a-c were then successfully purified by means of column chromatography on silica gel to obtain

Table 1. Transformation of 2-Bromomethyl-2-methylaziridines 4 to Functionalized Azetidines 7 and Aziridines 8

\begin{tabular}{|c|c|c|c|c|c|}
\hline entry & $\mathrm{R}$ & $\mathrm{Nu}$ & reaction conditions & ratio $7 / 8^{a}$ & yield 7 or 8 \\
\hline 1 & $\mathrm{H}$ & $\mathrm{SCN}$ & 1 equiv $\mathrm{KSCN}, 2 \mathrm{~h}, \Delta, \mathrm{MeCN}$ & $50 / 50$ & $7 a(45 \%)$ \\
\hline 2 & $\mathrm{Me}$ & SCN & 1 equiv $\mathrm{KSCN}, 3 \mathrm{~h}, \Delta, \mathrm{MeCN}$ & $57 / 43$ & $7 \mathbf{b}(55 \%)$ \\
\hline 3 & $\mathrm{OMe}$ & $\mathrm{SCN}$ & 1 equiv $\mathrm{KSCN}, 4 \mathrm{~h}, \Delta, \mathrm{MeCN}$ & $67 / 33$ & $7 c(65 \%)$ \\
\hline 4 & $\mathrm{Me}$ & $\mathrm{CN}$ & 2 equiv $\mathrm{KCN}, 26 \mathrm{~h}, \Delta, \mathrm{MeCN}$ & $100 / 0$ & $7 d(96 \%)$ \\
\hline 5 & $\mathrm{OMe}$ & $\mathrm{CN}$ & 2 equiv $\mathrm{KCN}, 26 \mathrm{~h}, \Delta$, $\mathrm{MeCN}$ & $100 / 0$ & $7 e(95 \%)$ \\
\hline 6 & $\mathrm{Me}$ & $\mathrm{OPh}$ & 2.2 equiv $\mathrm{PhOH}, 5$ equiv $\mathrm{K}_{2} \mathrm{CO}_{3}, 20 \mathrm{~h}, \Delta, \mathrm{MeCN}$ & $57 / 43$ & $7 f(47 \%)$ \\
\hline 8 & $\mathrm{Me}$ & OAc & 1.1 equiv $\mathrm{NaOAc}, 24 \mathrm{~h}, \Delta, \mathrm{MeCN}$ & $100 / 0$ & $7 \mathbf{h}(95 \%)$ \\
\hline 9 & $\mathrm{OMe}$ & OAc & 1.1 equiv $\mathrm{NaOAc}, 22 \mathrm{~h}, \Delta, \mathrm{MeCN}$ & $100 / 0$ & $7 \mathbf{i}(92 \%)$ \\
\hline 10 & $\mathrm{H}$ & $\mathrm{SCN}$ & 1 equiv $\mathrm{KSCN}, 15 \mathrm{~h}, 60-70^{\circ} \mathrm{C}, \mathrm{DMF}$ & $0 / 100$ & $8 \mathbf{a}(94 \%)$ \\
\hline 11 & $\mathrm{Me}$ & $\mathrm{SCN}$ & 1 equiv $\mathrm{KSCN}, 15 \mathrm{~h}, 60-70^{\circ} \mathrm{C}, \mathrm{DMF}$ & $0 / 100$ & $\mathbf{8 b}(95 \%)$ \\
\hline 12 & $\mathrm{OMe}$ & SCN & 1 equiv $\mathrm{KSCN}, 20 \mathrm{~h}, 60-70^{\circ} \mathrm{C}, \mathrm{DMF}$ & $0 / 100$ & $8 c(90 \%)$ \\
\hline 13 & $\mathrm{Me}$ & $\mathrm{CN}$ & 1 equiv $\mathrm{KCN}, 16 \mathrm{~h}, 50-60^{\circ} \mathrm{C}, \mathrm{DMF}$ & $0 / 100$ & $8 d(85 \%)$ \\
\hline 14 & $\mathrm{OMe}$ & $\mathrm{CN}$ & 1 equiv $\mathrm{KCN}, 16 \mathrm{~h}, 50-60^{\circ} \mathrm{C}$, DMF & $0 / 100$ & $8 \mathbf{e}(89 \%)$ \\
\hline 16 & $\mathrm{OMe}$ & $\mathrm{OPh}$ & 2.2 equiv $\mathrm{PhOH}, 5$ equiv $\mathrm{K}_{2} \mathrm{CO}_{3}, 14 \mathrm{~h}, 50^{\circ} \mathrm{C}$, DMF & $0 / 100$ & $8 g(90 \%)$ \\
\hline 17 & $\mathrm{Me}$ & OAc & 1.1 equiv $\mathrm{NaOAc}, 5$ days, r.t., DMSO & $20 / 80$ & $8 \mathrm{~h}(72 \%)$ \\
\hline 18 & $\mathrm{OMe}$ & OAc & 1.1 equiv $\mathrm{NaOAc}, 3$ days, r.t., DMSO & $25 / 75$ & $8 \mathbf{i}(45 \%)$ \\
\hline
\end{tabular}

${ }^{a}$ Determined based on ${ }^{1} \mathrm{H}$ NMR. 
analytically pure samples. Aziridines $\mathbf{8 a}-\mathbf{c}$ were susceptible to partial decomposition during the chromatographic purification process.

Bearing in mind the different reactivity profile of aziridines 4 toward $\mathrm{KSCN}$ in different solvents (MeCN versus DMF), 2bromomethyl-2-methylaziridines $\mathbf{4 b}, \mathbf{c}$ were then treated with other nucleophiles such as cyanide, phenoxide and acetate both in $\mathrm{MeCN}$ and DMF as the solvent medium (Scheme 3, Table 1).

After treatment of aziridines $4 \mathbf{b}, \mathbf{c}$ with 2 equiv of $\mathrm{KCN}$ in $\mathrm{MeCN}$ for $26 \mathrm{~h}$ at reflux temperature, only 3-cyano-3methylazetidines $\mathbf{7 d}$,e were obtained (entry 4-5, Table 1), whereas the same reaction in DMF gave exclusively 2cyanomethyl-2-methylaziridines $8 \mathrm{~d}$,e after $16 \mathrm{~h}$ at $50-60{ }^{\circ} \mathrm{C}$ (entry 13-14, Table 1). As in the case of thiocyanate $(\mathrm{Nu}=$ $\mathrm{SCN}$ ), the reaction outcome was shown to be dictated by the solvent used in these reactions, providing an efficient method for the synthesis of new functionalized aziridines and azetidines in a selective way. Azetidines $7 \mathbf{d}, \mathbf{e}$ and aziridines $\mathbf{8 d , e}$ were purified by means of column chromatography on silica gel to provide analytically pure samples.

The reaction of aziridines $\mathbf{4 b}$,c with 2.2 equiv of phenol and 5 equiv of $\mathrm{K}_{2} \mathrm{CO}_{3}$ in $\mathrm{MeCN}$ for $20-24 \mathrm{~h}$ was not so straightforward and gave mixtures of 3-methyl-3-phenoxyazetidines $\mathbf{7 f , g}$ and 2-methyl-2-(phenoxymethyl)aziridines $\mathbf{8 f , g}$, in which azetidines $\mathbf{7 f}, \mathbf{g}$ were present as the major isomers (ratio $7 / 8=57-67 / 43-33$, entry $6-7$, Table 1 ). These compounds were separated and isolated by means of column chromatography $\left(\mathrm{SiO}_{2}\right)$ to obtain analytically pure samples. On the other hand, treatment of aziridines $\mathbf{4 b}, \mathbf{c}$ with 2.2 equiv of phenol and 5 equiv of $\mathrm{K}_{2} \mathrm{CO}_{3}$ in DMF for $14-17 \mathrm{~h}$ at $50{ }^{\circ} \mathrm{C}$ provided 2methyl-2-(phenoxymethyl)aziridines $\mathbf{8 f ,} \mathbf{g}$ as the major products (entry $15-16$, Table 1$)$, and only small amounts $(\sim 10 \%)$ of azetidine $7 \mathbf{f}$ were observed. However, the purification by silica gel column chromatography did not provide completely pure products due to coelution of an unidentified side product in small quantities (10-15\%). Finally, when aziridines $4 b, c$ were subjected to 1.1 equiv of $\mathrm{NaOAc}$ in $\mathrm{MeCN}$ for $22-24 \mathrm{~h}$ at reflux temperature, 3-acetoxy-3-methylazetidines $7 \mathbf{h}, \mathbf{i}$ were produced without traces of the corresponding aziridines (entry 8-9, Table 1). On the other hand, the reaction of the same aziridines $\mathbf{4 b , c}$ with 1.1 equiv of $\mathrm{NaOAc}$ in DMF for $16-$ $20 \mathrm{~h}$ resulted in complex mixtures, in which the presence of 2 -

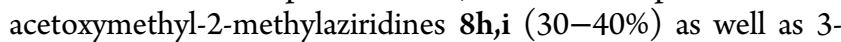
acetoxy-3-methylazetidines $7 \mathbf{h}, \mathbf{i}(10-20 \%)$ was acknowledged by means of ${ }^{1} \mathrm{H}$ NMR analysis. It should be mentioned that the reaction with $\mathrm{NaOAc}$ provided a unique case of noteworthy amounts of azetidine formation in DMF as the solvent, while in all other cases (except in the case of a small amount of azetidine 7f) the formation of azetidines using DMF as the solvent was not observed. After several attempts to optimize the reaction conditions in different solvents (DMF and DMSO), at different temperatures (r.t. to $100{ }^{\circ} \mathrm{C}$ ), and by using additional reagents (such as $\mathrm{AgBF}_{4}$ ), aziridines $\mathbf{8 h}$,i were finally obtained as the major compounds (ratio $7 / 8=20-25 / 80-75$ ) after treatment of aziridines $\mathbf{4 b , c}$ with 1.1 equiv of $\mathrm{NaOAc}$ in $\mathrm{DMSO}$ at room temperature for 3-5 days. Higher temperatures $\left(>30{ }^{\circ} \mathrm{C}\right)$ yielded complete conversion of the starting aziridines $4 b, c$ only after a few hours, however at the expense of selectivity of this reaction (ratio $7 / 8=40-50 / 60-50$ ). From these mixtures, aziridines $\mathbf{8 h}$,i could not be isolated in completely pure form by means of column chromatography on silica gel due to coelution of azetidines $7 \mathbf{h}, \mathbf{i}$ and small amounts of some side products (10-15\%).

The ratio $7 / 8$ was determined by spectroscopic analysis $\left({ }^{1} \mathrm{H}\right.$ NMR) of the crude reaction mixtures. After purification, the structures of the azetidines 7 and aziridines $\mathbf{8}$ were confirmed by means of different characterization methods $\left({ }^{1} \mathrm{H} \mathrm{NMR},{ }^{13} \mathrm{C}\right.$ NMR, IR, MS).

The selective transformation of aziridines 4 toward either azetidines $\mathbf{7}$ in acetonitrile or aziridines $\mathbf{8}$ in dimethylformamide (Scheme 4) provides interesting opportunities for further elaboration to valuable azaheterocycles.

Scheme 4. Selective Transformation of 2-Bromomethyl-2methylaziridines 4 to Functionalized Azetidines 7 and Aziridines 8

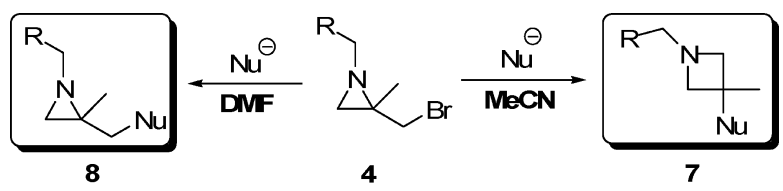

$\mathrm{Nu}=\mathrm{CN}, \mathrm{OAc}, \mathrm{OPh}, \mathrm{SCN}$

From a mechanistic point of view, different pathways can be considered to explain the synthesis of functionalized aziridines and azetidines starting from 2-bromomethyl-2-methylaziridines 4. An overview of possible reactivity profiles of aziridines 4 in $\mathrm{MeCN}$ is presented in Scheme 5. Bearing in mind the

Scheme 5. Possible Synthetic Routes for the Formation of Azetidines 7 and Aziridines 8 from Aziridines 4 in $\mathrm{MeCN}$ mediated Reactions

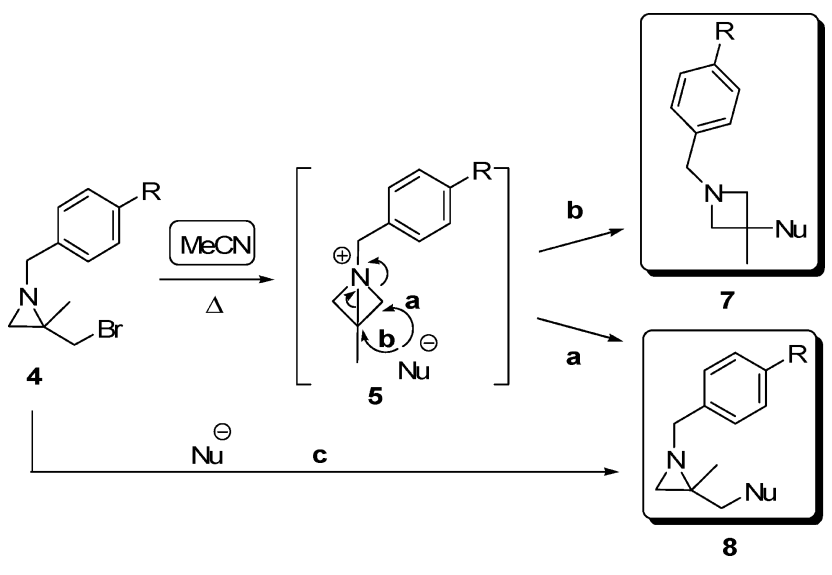

previously reported intermediacy of bicyclic aziridinium ions in the synthesis of 3-methoxy-3-methylazetidines starting from 2bromomethyl-2-methylaziridines, ${ }^{16}$ the nucleophilic attack at the more hindered carbon atom of the strained intermediates 5 (path b, Scheme 5) is considered to be the most plausible route for the formation of 3 -substituted azetidines 7 in $\mathrm{MeCN}$, possibly through the less stable nonbridged carbenium ion. This fact is also in accordance with the ring transformation of 2bromomethyl-2-methylaziridines $\mathbf{4 a - c}$ in $\mathrm{MeCN}$ at reflux temperature (Scheme 2). It should be noted that in some cases (entries $1-3,6,7$, Table 1 ) the formation of aziridines 8 was observed as well (33-50\%). The presence of aziridines 8 in these $\mathrm{MeCN}$-mediated reactions can be attributed to nucleophilic attack at the less-hindered carbon atom of the bicyclic aziridinium ions 5 (path a, Scheme 5), taking into 
account a few isolated literature examples on the ring opening of strained bicyclic intermediates. ${ }^{19}$ However, direct nucleophilic displacement of bromide in 2-bromomethyl-2-methylaziridines 4 by the nucleophile (path c, Scheme 5) will most probably prevail as the pathway toward substituted aziridines $\mathbf{8}$.

The proposed mechanistic pathways for the selective formation of aziridines 8 in DMF are depicted in Scheme 6.

Scheme 6. Possible Synthetic Routes for the Formation of Aziridines 8 from Aziridines 4 in DMF-mediated Reactions

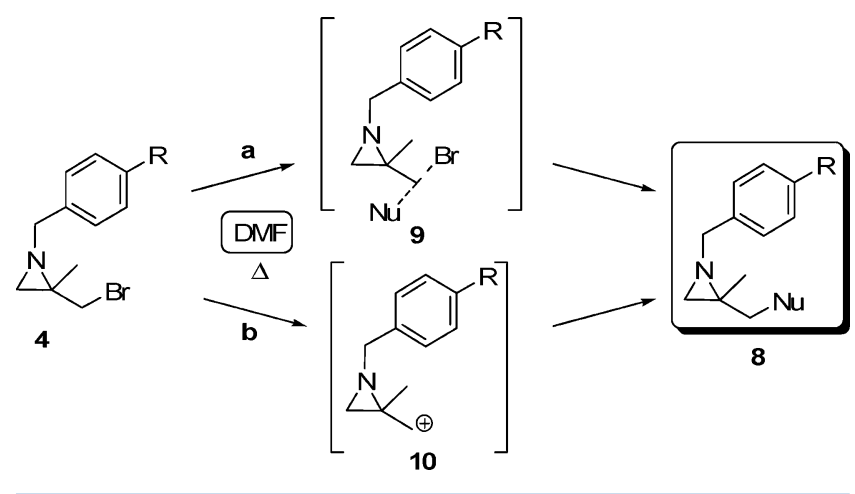

Herein, two different routes can be considered, involving either direct displacement of bromide by the approaching nucleophile via a $S_{N} 2$ protocol (path a, intermediate 9 , Scheme 6) or via the formation of primary carbenium ions $10\left(S_{N} 1\right.$ mechanism, path b, Scheme 6), which might be stabilized by the nitrogen lone pair through anchimeric assistance. The formation of aziridines $\mathbf{8}$ via nucleophilic attack at the less-substituted carbon atom of bicyclic aziridinium intermediates 5 (path a, Scheme 5) in DMF should not be completely neglected, although the fact that aziridines 4 do not rearrange into azetidines $\mathbf{6}$ upon heating in DMF for several hours suggests that no bicyclic aziridinium species $\mathbf{5}$ are formed in these reactions.

To shed more light on the remarkable preference for the formation of azetidines in $\mathrm{MeCN}$ and aziridines in DMF (Schemes 5 and 6), some computational analyses were performed.

Theoretical Rationalization. The solvent-dependent reactivity of different nucleophiles toward 2-bromomethyl-2methylaziridines was further investigated by means of DFT calculations. The difference in the observed selectivity in DMF and $\mathrm{MeCN}$ was unexpected, since both solvents are polar and aprotic, and have very similar dielectric constants (36.71 and 35.94, respectively). However, they have different densities (943.87 and $776.49 \mathrm{~kg} \mathrm{~m}^{-3}$, respectively), molar volumes (77.442 and $52.870 \mathrm{~cm}^{3} \mathrm{~mol}^{-1}$, respectively), shapes and dipoles. The latter properties of DMF and MeCN can influence the way they solvate ions, and ion solvation is known to be correlated with rate constants of chemical reactions. ${ }^{20}$ Free energies of solvation of relevant ions in DMF and $\mathrm{MeCN}$ are quite similar, e.g. 251 and $256 \mathrm{~kJ} \mathrm{~mol}^{-1}$ for $\mathrm{Br}^{-}, 243$ and $248 \mathrm{~kJ}$ $\mathrm{mol}^{-1}$ for $\mathrm{CN}^{-}$and 213 and $217 \mathrm{~kJ} \mathrm{~mol}^{-1}$ for $\mathrm{SCN}^{-}$, respectively, ${ }^{21}$ but the difference in close-packing can be crucial for their relative reactivities, i.e. this can influence how free the nucleophiles are to attack and how willing the nucleophuge is to leave. This notion will be investigated with computational methods.

Computational Methodology. The B3LYP/6-31+G(d,p) level of theory was used for geometry optimizations of clusters of ions and solvent molecules. ${ }^{22}$ Stationary points were characterized as minima (ground states) via frequency calculations. The B3LYP functional has been proven to produce good geometries, but is less accurate for energy calculations. $^{23}$ Therefore energies were refined with the MPW1K functional, which has shown its utility for energy calculations. ${ }^{24}$ Previous computational studies have demonstrated the necessity of $d$ and $f$ polarization functions on the sulfur basis set, ${ }^{25}$ hence, the MPW1K functional was used in conjunction with the $6-311+\mathrm{G}(3 \mathrm{df}, 2 \mathrm{p})$ basis set for sulfur and the $6-31++G(d, p)$ basis set for all other atoms, since this method was shown to be adequate for calculations on sulfurcontaining systems. $^{24 \mathrm{e}}$ All thermal free energy corrections reported were taken from $B 3 L Y P / 6-31+G(d, p)$ optimizations at $1 \mathrm{~atm}$ and $298 \mathrm{~K}$. All computations were performed with the Gaussian 09 program packages. ${ }^{26}$

Coordination Solvation Energies. As briefly mentioned earlier, a different close-packing of the nucleophiles $\left(\mathrm{CN}^{-}\right.$and $\mathrm{SCN}^{-}$), the nucleophuge $\mathrm{Br}^{-}$or even the bicyclic aziridinium intermediate 5 by $\mathrm{DMF}$ and $\mathrm{MeCN}$ could be very important for the relative reactivity of these ions. To investigate the closepacking, the convergence behavior of the energy of coordination solvation was inspected by means of systematically increasing the number of explicit solvent molecules around the ions, and the corresponding coordination solvation energies (CSE's) and coordination solvation free energies (CSG's) were calculated. ${ }^{24 e, f, 27}$ CSG's are known to converge before CSE's, which is merely caused by entropic effects. CSE's are listed in the Supporting Information.

It has recently been reported that rearrangement of 2bromomethyl-2-methylaziridines $1\left(\mathrm{R}^{2}=\mathrm{Me}\right)$ with $\mathrm{NaBH}_{4}$ in $\mathrm{MeOH}$ toward 3-methoxy-3-methylazetidines 3 (Scheme 1) takes place via a bicyclic aziridinium ion. ${ }^{16}$ Free energies of activation for the formation of the bicyclic intermediate were found to be reasonable and the bicyclic intermediate was found to be far more stable than its nonbridged counterpart. Therefore, it is likely that the rearrangement of aziridines 4 toward azetidines 7 takes place via a bicyclic aziridinium species 5 (Scheme 5).

Coordination of the bicyclic aziridinium species 5 by DMF and $\mathrm{MeCN}$ is shown in Figures 1 and 2, respectively. From experimental data, it is clear that this intermediate was formed in $\mathrm{MeCN}$ (Table 1) but not in DMF (Table 1). A possible explanation is a better stabilization of intermediate $\mathbf{5}$ in $\mathrm{MeCN}$ than in DMF. From the coordination solvation energies, stabilization of $\mathbf{5}$ does not seem to cause the difference in reactivity in $\mathrm{DMF}$ and $\mathrm{MeCN}$, since coordination at the most accessible places by both solvents gives rise to a stronger coordination with DMF than with $\mathrm{MeCN}\left(\mathrm{CSG}_{\mathrm{MPW} 1 \mathrm{~K}}=-49.7\right.$ and $-34.6 \mathrm{~kJ} / \mathrm{mol}$ for $\mathrm{DMF}$ and $\mathrm{MeCN}$, respectively, Figures 1 and 2). This is understandable, since the DMF oxygen and the $\mathrm{MeCN}$ nitrogen interact with the hydrogen atoms of 5, and oxygen is more electronegative than nitrogen. This can also be seen in the distances between the hydrogen atoms of $\mathbf{5}$ and both the DMF oxygen atoms $(2.29-2.65 \AA)$ and the $\mathrm{MeCN}$ nitrogen atoms (2.50-2.84 $\AA$ ). Moreover, coordination solvation energies for both solvents converge with 3 solvent molecules, thus coordination with more solvent molecules is not expected to make a substantial difference. The closepacking of 5 by DMF could avoid it from getting attacked by a nucleophile to give azetidine 7 , while 5 is more readily available for nucleophilic attack in $\mathrm{MeCN}$.

The difference in observed regioselectivity in DMF and $\mathrm{MeCN}$ can alternatively be due to a stronger coordination and 

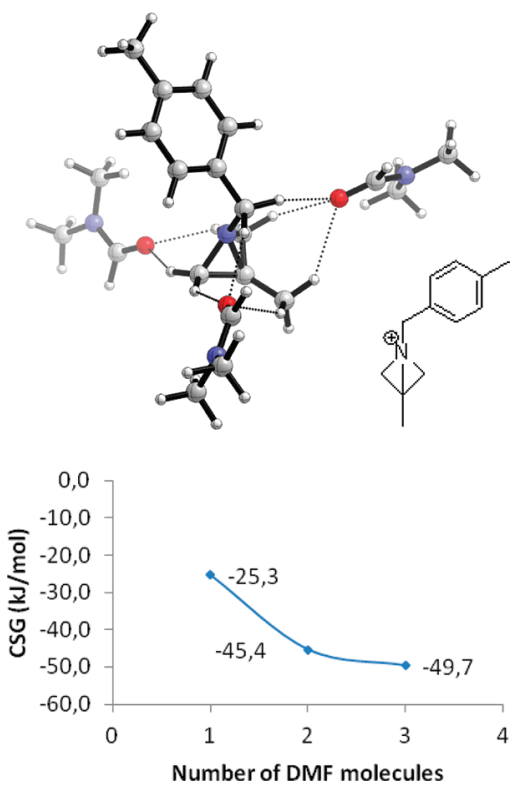

Figure 1. Coordination of the bicyclic aziridinium $\mathbf{5 b}$ by an increasing number of DMF molecules. MPW1K/6-31++G(d,p)//B3LYP/6$31+G(d, p)$. 5b with 3 DMF molecules shown in figure. Distances between the hydrogen atoms of $\mathbf{5}$ and the DMF oxygen atoms are 2.29-2.65 Å.
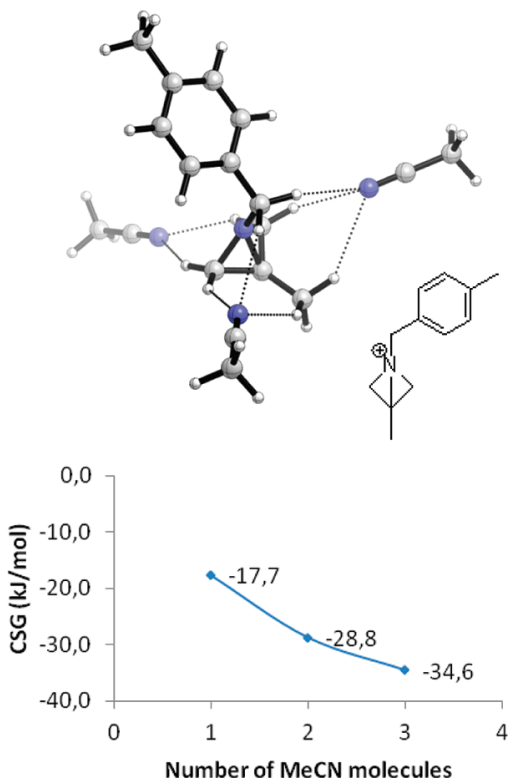

Figure 2. Coordination of the bicyclic aziridinium $\mathbf{5 b}$ by an increasing number of $\mathrm{MeCN}$ molecules. MPW1K/6-31++G(d,p)//B3LYP/6$31+\mathrm{G}(\mathrm{d}, \mathrm{p})$. 5b with $3 \mathrm{MeCN}$ molecules shown in figure. Distances between the hydrogen atoms of $\mathbf{5}$ and the $\mathrm{MeCN}$ nitrogen atoms are 2.50-2.84 A.

better stabilization of the nucleophile by $\mathrm{MeCN}$ and hence, a higher probability for the formation of the bicyclic intermediate 5 in $\mathrm{MeCN}$-with subsequent formation of azetidine 7-over the direct replacement of $\mathrm{Br}^{-}$by the nucleophile in aziridine 4 and formation of aziridine 8 (Scheme 4). Coordination of the nucleophile $\mathrm{CN}^{-}$by DMF and $\mathrm{MeCN}$ is shown in Figures 3 and 4, respectively. Coordination of $\mathrm{CN}^{-}$with three explicit DMF or MeCN molecules shows that $\mathrm{CN}^{-}$is strongly coordinated and thus better stabilized by $\mathrm{MeCN}$ than by DMF $\left(\mathrm{CSG}_{\mathrm{MPW} 1 \mathrm{~K}}=-41.0\right.$ and $-56.3 \mathrm{~kJ} / \mathrm{mol}$ for $\mathrm{DMF}$ and
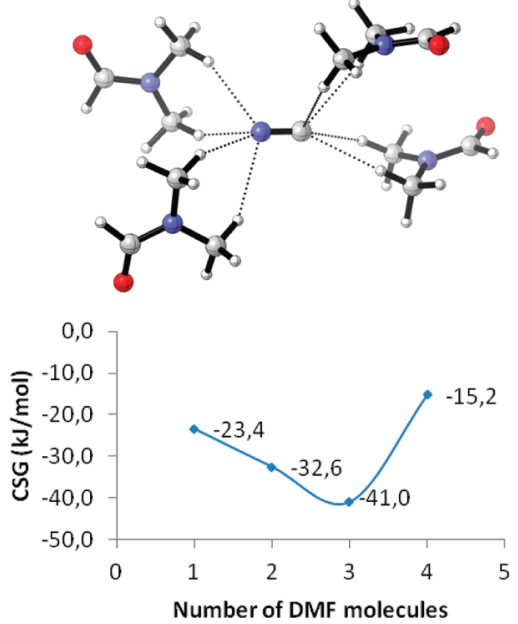

Figure 3. Coordination of $\mathrm{CN}^{-}$by an increasing number of DMF molecules. MPW1K/6-31++G(d,p)//B3LYP/6-31+G(d,p). $\mathrm{CN}^{-}$with $4 \mathrm{DMF}$ molecules shown in figure. Distances between the hydrogen atoms of DMF and the $\mathrm{CN}^{-}$nitrogen and carbon are 2.40-2.67 and 2.57-2.89 ̊̊, respectively.

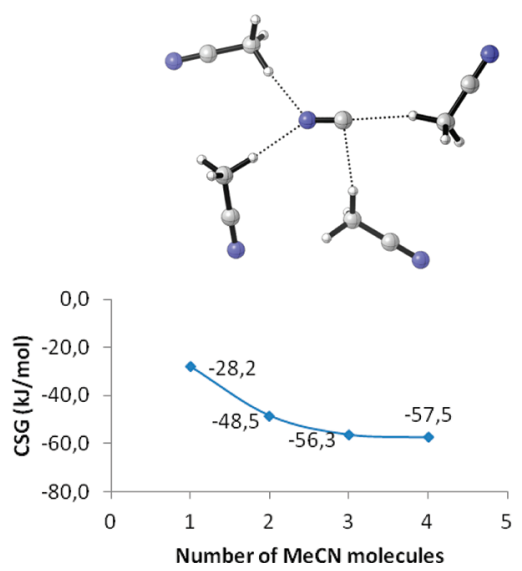

Figure 4. Coordination of $\mathrm{CN}^{-}$by an increasing number of $\mathrm{MeCN}$ molecules. MPW1K/6-31++G(d,p)//B3LYP/6-31+G(d,p). $\mathrm{CN}^{-}$with $4 \mathrm{MeCN}$ molecules shown in figure. Distances between the hydrogen atoms of $\mathrm{MeCN}$ and the $\mathrm{CN}^{-}$nitrogen and carbon are 2.14-2.17 and 2.36-2.51 $\AA$, respectively.

$\mathrm{MeCN}$, respectively). Furthermore, $\mathrm{MeCN}$ molecules can pack more closely than DMF molecules, as seen in the relative distances between the hydrogen atoms of the solvent and the $\mathrm{CN}^{-}$nitrogen (2.40-2.67 and 2.14-2.17 $\AA$ in DMF and $\mathrm{MeCN}$, respectively) and the $\mathrm{CN}^{-}$carbon (2.57-2.89 and 2.36-2.51 $\AA$ in DMF and $\mathrm{MeCN}$, respectively). Coordination solvation energies for $\mathrm{DMF}$ and $\mathrm{MeCN}$ converge after coordination with three and four molecules, respectively, and two hydrogen atoms of each DMF molecule can coordinate with $\mathrm{CN}^{-}$while only one hydrogen atom of $\mathrm{MeCN}$ coordinates with $\mathrm{CN}^{-}$, but the bulky DMF methyl groups prevent the DMF molecules from packing closely. The stronger coordination and better stabilization of $\mathrm{CN}^{-}$by $\mathrm{MeCN}$ can point to a lower reactivity, hence allowing the formation of azetidine 7 via formation of the bicyclic intermediate 5. Since $\mathrm{CN}^{-}$is less stabilized in DMF, it will be more reactive and hence, nucleophilic substitution in aziridine $\mathbf{4}$ will lead to aziridine 8 .

In the case of the nucleophile $\mathrm{SCN}^{-}$, a mixture of both 7 and $\mathbf{8}$ is experimentally observed. Hence, the difference between the 
coordination solvation of $\mathrm{CN}^{-}$and $\mathrm{SCN}^{-}$can illustrate the reasoning behind this experimental observation. Coordination of $\mathrm{SCN}^{-}$by DMF and $\mathrm{MeCN}$ is shown in Figures 5 and 6 ,
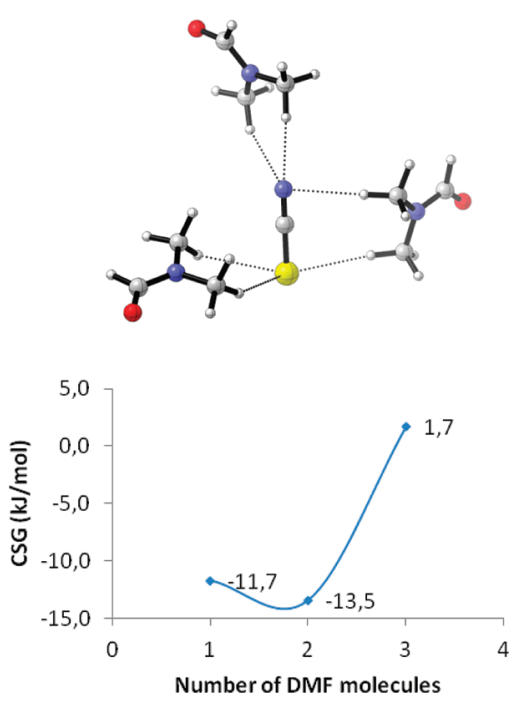

Figure 5. Coordination of $\mathrm{SCN}^{-}$by an increasing number of DMF molecules. MPW1K/6-31++G(d,p)//B3LYP/6-31+G(d,p). SCN ${ }^{-}$ with 3 DMF molecules shown in figure. Distances between the hydrogen atoms of DMF and the $\mathrm{SCN}^{-}$nitrogen and sulfur are $2.40-$ 2.64 and $3.03-3.11 \AA$, respectively.
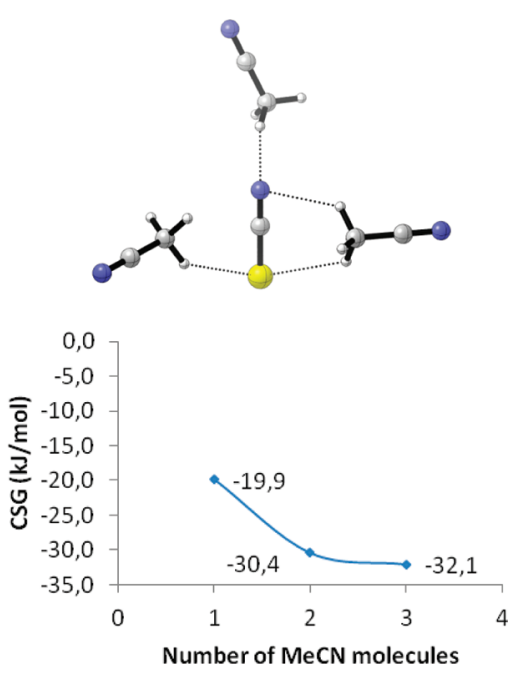

Figure 6. Coordination of $\mathrm{SCN}^{-}$by an increasing number of $\mathrm{MeCN}$ molecules. MPW1K/6-31++G(d,p)//B3LYP/6-31+G(d,p). SCN with $3 \mathrm{MeCN}$ molecules shown in figure. Distances between the hydrogen atoms of $\mathrm{MeCN}$ and the $\mathrm{SCN}^{-}$nitrogen and sulfur are $2.22-2.72$ and $2.93-3.07 \AA$, respectively.

respectively. Coordination of $\mathrm{SCN}^{-}$with two explicit DMF or $\mathrm{MeCN}$ molecules shows that $\mathrm{SCN}^{-}$is strongly coordinated and thus better stabilized in $\mathrm{MeCN}$ as the solvent as compared to $\mathrm{DMF}$ as the solvent $\left(\mathrm{CSG}_{\mathrm{MPW} 1 \mathrm{~K}}=-13.5\right.$ and $-30.4 \mathrm{~kJ} / \mathrm{mol}$ for $\mathrm{DMF}$ and $\mathrm{MeCN}$, respectively). Coordination solvation energies for $\mathrm{SCN}^{-}$with $\mathrm{DMF}$ and $\mathrm{MeCN}$ converge after coordination with two and three molecules, respectively. However, in this case the packing distances of $\mathrm{MeCN}$ and DMF molecules are not strikingly different. On the other hand, $\mathrm{MeCN}$ molecules pack more closely to $\mathrm{CN}^{-}$than to $\mathrm{SCN}^{-}$ (distances between the hydrogen atoms of $\mathrm{MeCN}$ and the $\mathrm{CN}^{-}$ and $\mathrm{SCN}^{-}$nitrogen are $2.14-2.17$ and $2.22-2.72 \AA$, respectively, and distances between the hydrogen atoms of $\mathrm{MeCN}$ and the $\mathrm{CN}^{-}$carbon and $\mathrm{SCN}^{-}$sulfur are 2.36-2.51 and 2.93-3.07 $\AA$, respectively). This, together with the difference between the coordination solvation energies of $\mathrm{CN}^{-}$and $\mathrm{SCN}^{-}$in $\mathrm{MeCN}\left(\mathrm{CSG}_{\mathrm{MPW} 1 \mathrm{~K}}=-56.3\right.$ and -32.1 , respectively) could explain why both the formation of the bicyclic intermediate 5 and nucleophilic substitution in aziridine 4 are possible for $\mathrm{SCN}^{-}$in $\mathrm{MeCN}$.

For completeness, coordination of $\mathrm{Br}^{-}$by DMF and $\mathrm{MeCN}$ is shown in Figures 7 and 8, respectively. Like $\mathrm{CN}^{-}, \mathrm{Br}^{-}$is
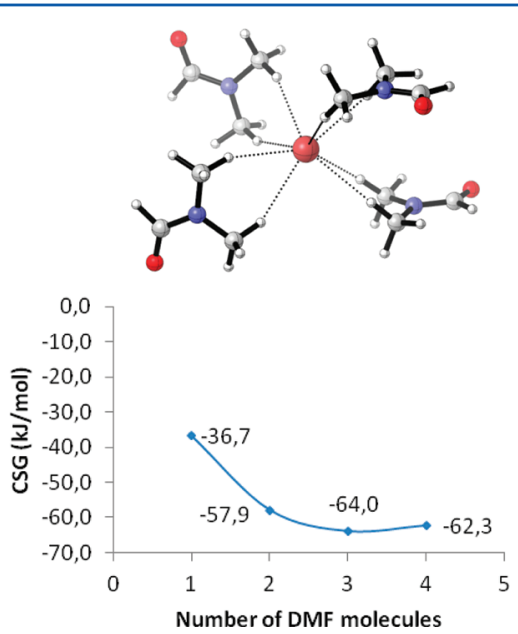

Figure 7. Coordination of $\mathrm{Br}^{-}$by an increasing number of DMF molecules. MPW $1 \mathrm{~K} / 6-31++\mathrm{G}(\mathrm{d}, \mathrm{p}) / / \mathrm{B} 3 \mathrm{LYP} / 6-31+\mathrm{G}(\mathrm{d}, \mathrm{p}) . \mathrm{Br}^{-}$with 4 DMF molecules shown in figure. Distances between the hydrogen atoms of DMF and $\mathrm{Br}^{-}$are 2.76-2.87 $\AA$.

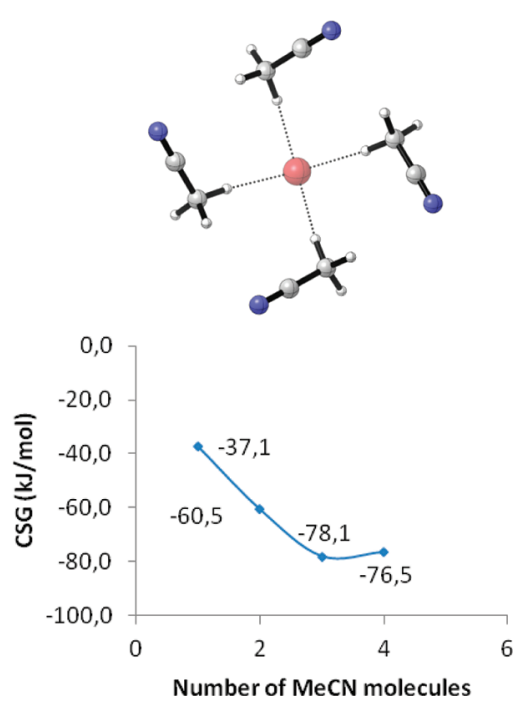

Figure 8. Coordination of $\mathrm{Br}^{-}$by an increasing number of $\mathrm{MeCN}$ molecules. MPW1K/6-31++G(d,p)//B3LYP/6-31+G(d,p). Br ${ }^{-}$with $4 \mathrm{MeCN}$ molecules shown in figure. Distances between the hydrogen atoms of $\mathrm{MeCN}$ and $\mathrm{Br}^{-}$are $2.60 \AA$.

strongly coordinated and thus better stabilized by $\mathrm{MeCN}$ than by DMF $\left(\mathrm{CSG}_{\mathrm{MPW} 1 \mathrm{~K}}=-64.0\right.$ and $-78.1 \mathrm{~kJ} / \mathrm{mol}$ for three explicit $\mathrm{DMF}$ and $\mathrm{MeCN}$ molecules, respectively). The stronger coordination of $\mathrm{Br}^{-}$by $\mathrm{MeCN}$ can improve its leaving group capacity and thus help in the formation of the bicyclic intermediate $\mathbf{5}$. 
Thus, stabilization of $\mathbf{5}$ does not seem to cause the difference in reactivity in DMF and MeCN but the close-packing of 5 by DMF could avoid it from getting attacked by a nucleophile. Furthermore, the stronger coordination and better stabilization of $\mathrm{CN}^{-}$by $\mathrm{MeCN}$ can point to a lower reactivity, hence allowing the formation of azetidine 7 via formation of the bicyclic intermediate 5. Since $\mathrm{CN}^{-}$is less stabilized in DMF, it will be more reactive, and hence, nucleophilic substitution of aziridine 4 will lead to aziridine 8 . The weaker coordination of $\mathrm{SCN}^{-}$by $\mathrm{MeCN}$, compared to $\mathrm{CN}^{-}$, could explain why both the formation of the bicyclic intermediate 5 and nucleophilic substitution in the aziridine 4 are possible for $\mathrm{SCN}^{-}$in $\mathrm{MeCN}$. Finally, the stronger coordination of $\mathrm{Br}^{-}$by $\mathrm{MeCN}$ can improve its leaving group capacity and thus help in the formation of the bicyclic intermediate 5 .

In summary, the reactivity of 2-bromomethyl-2-methylaziridines 4 with regard to different carbon, oxygen and sulfur nucleophiles was investigated, providing an efficient strategy toward the selective synthesis of a large variety of functionalized aziridines and azetidines. The reaction outcome was proven to be controlled by the choice of the solvent, showing DMF to be a suitable solvent for the synthesis of the corresponding aziridines 8 and $\mathrm{MeCN}$ for the synthesis of the corresponding azetidines 7 as major compounds via strained bicyclic intermediates. To account for the experimentally observed results, DFT calculations were employed to elucidate the extraordinary preference for the formation of azetidines in $\mathrm{MeCN}$ and aziridines in DMF.

\section{EXPERIMENTAL PART}

General. ${ }^{1} \mathrm{H}$ NMR spectra were recorded at $300 \mathrm{MHz}$ with $\mathrm{CDCl}_{3}$ as solvent and tetramethylsilane as internal standard. ${ }^{13} \mathrm{C}$ NMR spectra were recorded at $75 \mathrm{MHz}$ with $\mathrm{CDCl}_{3}$ as solvent. Mass spectra were recorded using either a direct inlet system (electron spray, $4000 \mathrm{~V}$ ) or LC-MS coupling (UV detector). IR spectra were recorded on a FT-IR spectrometer. All compounds were analyzed in neat form with an ATR (Attenuated Total Reflectance) accessory. Dichloromethane was distilled over calcium hydride, while diethyl ether and THF were distilled from sodium and sodium benzophenone ketyl before use.

Synthesis of 3-Bromo-3-methylazetidines $6 a, c$. As a representative example, the synthesis of 1-benzyl-3-bromo-3-methylazetidine $\mathbf{6 a}$ is described here. 1-Benzyl-2-bromomethyl-2-methylaziridine 4a $(1.20 \mathrm{~g}, 5 \mathrm{mmol})$ was dissolved in acetonitrile $(30 \mathrm{~mL})$, and the mixture was heated at reflux temperature for $15 \mathrm{~h}$. The reaction mixture was cooled to room temperature, poured into water $(20 \mathrm{~mL})$ and extracted with $\mathrm{CH}_{2} \mathrm{Cl}_{2}(3 \times 20 \mathrm{~mL})$. The combined organic extracts were washed with $\mathrm{H}_{2} \mathrm{O}(2 \times 15 \mathrm{~mL})$ and brine $(20 \mathrm{~mL})$. Drying $\left(\mathrm{MgSO}_{4}\right)$, filtration of the drying agent and evaporation of the solvent in vacuo afforded 1-benzyl-3-bromo-3-methylazetidine 6a $(0.86 \mathrm{~g}, 72 \%)$, which was purified by silica gel column chromatography (petroleum ether/ethyl acetate 7/1) to obtain an analytically pure sample.

1-Benzyl-3-bromo-3-methylazetidine 6 a . Yellow oil; $R_{\mathrm{f}}=0.30$ (petroleum ether/ethyl acetate 7/1); Yield, 72\%; isolated yield, $62 \%$ (after purification); ${ }^{1} \mathrm{H}$ NMR $\left(300 \mathrm{MHz}, \mathrm{CDCl}_{3}\right) \delta 2.00(3 \mathrm{H}, s), 3.52$ $(2 \mathrm{H}, d, J=9.1 \mathrm{~Hz}), 3.69(2 \mathrm{H}, d, J=9.1 \mathrm{~Hz}), 3.71(2 \mathrm{H}, s), 7.21-7.33$ $(5 \mathrm{H}, m) ;{ }^{13} \mathrm{C}$ NMR $\left(75 \mathrm{MHz}\right.$, ref $\left.=\mathrm{CDCl}_{3}\right) \delta 31.6\left(\mathrm{CH}_{3}\right), 51.9(\mathrm{C})$, 63.2 $\left(\mathrm{CH}_{2}\right), 70.9\left(2 \times \mathrm{CH}_{2}\right), 127.3(2 \times \mathrm{CH}), 128.5(3 \times \mathrm{CH}), 137.8$ (C); IR (neat, $\left.\mathrm{cm}^{-1}\right) \nu_{\max }=2924,2844,1495,1453,1362,1245,1208$, 1181, 746, 696; MS $m / z$ (\%) 240/2 $\left(\mathrm{M}^{+}+1,100\right)$.

3-Bromo-1-(4-methoxybenzyl)-3-methylazetidine 6c. Yellow oil; $R_{f}=0.22$ (petroleum ether/ethyl acetate 7/1); Yield, 70\%; isolated yield, 59\% (after purification); ${ }^{1} \mathrm{H}$ NMR (300 $\left.\mathrm{MHz}, \mathrm{CDCl}_{3}\right) \delta 1.99$ $(3 \mathrm{H}, s), 3.49(2 \mathrm{H}, d, J=9.1 \mathrm{~Hz}), 3.67(2 \mathrm{H}, d, J=9.1 \mathrm{~Hz}), 3.64(2 \mathrm{H}$, s), $3.79(3 \mathrm{H}, s), 6.83-6.86$ and $7.18-7.20(4 \mathrm{H}, 2 \times m) ;{ }^{13} \mathrm{C} \mathrm{NMR}(75$ $\mathrm{MHz}$, ref $\left.=\mathrm{CDCl}_{3}\right) \delta 31.6\left(\mathrm{CH}_{3}\right), 52.0(\mathrm{C}), 55.3\left(\mathrm{CH}_{3}\right), 62.6\left(\mathrm{CH}_{2}\right)$, $70.7\left(2 \times \mathrm{CH}_{2}\right), 113.8(2 \times \mathrm{CH}), 129.7(2 \times \mathrm{CH}), 129.1(\mathrm{C}), 158.9$ (C); IR (neat, $\left.\mathrm{cm}^{-1}\right) \nu_{\max }=2930,2835,1612,1511,1243,1171,1034$, 819, 738, 696; MS $m / z$ (\%) $240 / 2\left(\mathrm{M}^{+}+1,100\right)$.

Synthesis of 3-Methyl-3-thiocyanatoazetidines 7a-c. As a representative example, the synthesis of 1-(4-methoxybenzyl)-3methyl-3-thiocyanatoazetidine $7 \mathrm{c}$ is described here. 2-Bromomethyl1-(4-methoxybenzyl)-2-methylaziridine $4 \mathrm{c}(1.35 \mathrm{~g}, 5 \mathrm{mmol})$ was dissolved in acetonitrile $(30 \mathrm{~mL})$, after which $\mathrm{KSCN}$ ( $0.49 \mathrm{~g}, 1$ equiv) was added and the mixture was heated at reflux temperature for $4 \mathrm{~h}$. The reaction mixture was cooled to room temperature, poured into water $(20 \mathrm{~mL})$ and extracted with $\mathrm{CH}_{2} \mathrm{Cl}_{2}(3 \times 20 \mathrm{~mL})$. The combined organic extracts were washed with $\mathrm{H}_{2} \mathrm{O}(2 \times 15 \mathrm{~mL})$ and brine $(20 \mathrm{~mL})$. Drying $\left(\mathrm{MgSO}_{4}\right)$, filtration of the drying agent and evaporation of the solvent afforded a mixture of 1-(4-methoxybenzyl)3-methyl-3-thiocyanatoazetidine $7 \mathrm{c}$ and 2-methyl-2(thiocyanatomethyl)aziridine $8 \mathrm{c}(7 \mathrm{c} / 8 \mathrm{c}=$ ratio $67 / 33)$, from which 1-(4-methoxybenzyl)-3-methyl-3-thiocyanatoazetidine $7 \mathrm{c}$ (0.94 g, $65 \%$ ) was isolated in pure form by preparative thin layer chromatography on silica gel (hexane/ethyl acetate/triethylamine 1/ $1 / 0.01$ ) to obtain an analytically pure sample.

1-Benzyl-3-methyl-3-thiocyanatoazetidine 7a. Yellow oil; $R_{\mathrm{f}}=$ 0.20 (hexane/ethyl acetate/triethylamine 1/1/0.01); Yield, 45\%; isolated yield, $36 \%$ (after purification); ${ }^{1} \mathrm{H}$ NMR (300 $\mathrm{MHz}$, $\left.\mathrm{CDCl}_{3}\right) \delta 1.79(3 \mathrm{H}, s), 3.35(2 \mathrm{H}, d, J=8.8 \mathrm{~Hz}), 3.47(2 \mathrm{H}, d, J=$ $8.8 \mathrm{~Hz}), 3.69(2 \mathrm{H}, s), 7.24-7.35(5 \mathrm{H}, m) ;{ }^{13} \mathrm{C} \mathrm{NMR}(75 \mathrm{MHz}$, ref $=$ $\left.\mathrm{CDCl}_{3}\right) \delta 26.4\left(\mathrm{CH}_{3}\right), 47.5(\mathrm{C}), 62.5\left(\mathrm{CH}_{2}\right), 66.3\left(2 \times \mathrm{CH}_{2}\right), 111.5$ (C), $127.5(\mathrm{CH}), 128.5(2 \times \mathrm{CH}), 128.6(2 \times \mathrm{CH}), 137.2(\mathrm{C})$; IR (neat, $\left.\mathrm{cm}^{-1}\right) \nu_{\mathrm{SCN}}=2151 ; \mathrm{MS} m / z(\%) 219\left(\mathrm{M}^{+}+1,100\right)$.

3-Methyl-1-(4-methybenzyl)-3-thiocyanatoazetidine 7b. Yellow oil; $R_{\mathrm{f}}=0.22$ (hexane/ethyl acetate/triethylamine 1/1/0.01); Yield, $55 \%$; isolated yield, $47 \%$ (after purification); ${ }^{1} \mathrm{H}$ NMR (300 MHz, $\left.\mathrm{CDCl}_{3}\right) \delta 1.78(3 \mathrm{H}, s), 2.33(3 \mathrm{H}, s), 3.33(2 \mathrm{H}, d, J=8.8 \mathrm{~Hz}), 3.46$ $(2 \mathrm{H}, d, J=8.8 \mathrm{~Hz}), 3.64(2 \mathrm{H}, s), 7.11-7.18(4 \mathrm{H}, m) ;{ }^{13} \mathrm{C}$ NMR $(75$ $\mathrm{MHz}$, ref $\left.=\mathrm{CDCl}_{3}\right) \delta 21.2\left(\mathrm{CH}_{3}\right), 26.4\left(\mathrm{CH}_{3}\right), 47.5(\mathrm{C}), 62.3\left(\mathrm{CH}_{2}\right)$, $66.2\left(2 \times \mathrm{CH}_{2}\right), 111.5(\mathrm{C}), 128.5(2 \times \mathrm{CH}), 129.2(2 \times \mathrm{CH}), 134.1$ (C), 137.1 (C); IR (neat, $\left.\mathrm{cm}^{-1}\right) \nu_{\mathrm{SCN}}=2151 ; \mathrm{MS} \mathrm{m} / z(\%) 233\left(\mathrm{M}^{+}+\right.$ $1,100)$.

1-(4-Methoxybenzyl)-3-methyl-3-thiocyanatoazetidine 7c. Yellow oil; $R_{\mathrm{f}}=0.18$ (hexane/ethyl acetate/triethylamine 1/1/0.01); Yield, 65\%; isolated yield, 52\% (after purification); ${ }^{1} \mathrm{H}$ NMR (300 $\left.\mathrm{MHz}, \mathrm{CDCl}_{3}\right) \delta 1.78(3 \mathrm{H}, s), 3.32(2 \mathrm{H}, d, J=9.4 \mathrm{~Hz}), 3.44(2 \mathrm{H}, d, J=$ $9.4 \mathrm{~Hz}), 3.62(2 \mathrm{H}, s), 3.80(3 \mathrm{H}, s), 6.84-6.87$ and $7.18-7.20(4 \mathrm{H}, 2 \times$ $m) ;{ }^{13} \mathrm{C}$ NMR $\left(75 \mathrm{MHz}\right.$, ref $\left.=\mathrm{CDCl}_{3}\right) \delta 26.4\left(\mathrm{CH}_{3}\right), 47.5(\mathrm{C}), 55.4$ $\left(\mathrm{CH}_{3}\right), 61.9\left(\mathrm{CH}_{2}\right), 66.1\left(2 \times \mathrm{CH}_{2}\right), 111.5(\mathrm{C}), 113.9(2 \times \mathrm{CH}), 129.2$ (C), $129.8(2 \times \mathrm{CH}), 159.0$ (C); IR (neat, $\left.\mathrm{cm}^{-1}\right) \nu_{\mathrm{SCN}}=2151 ; \mathrm{MS} \mathrm{m} /$ $z$ (\%) $249\left(\mathrm{M}^{+}+1,100\right)$; HRMS $\mathrm{m} / z$ (ESI) calculated for $\mathrm{C}_{13} \mathrm{H}_{16} \mathrm{~N}_{2} \mathrm{OS}[\mathrm{MH}]^{+}$249.1062, found 249.1059.

Synthesis of 2-Methyl-2-(thiocyanatomethyl)aziridines $\mathbf{8 a}$ c. As a representative example, the synthesis of 2-methyl-1-(4methylbenzyl)-2-(thiocyanatomethyl)aziridine $\mathbf{8 b}$ is described here. 2Bromomethyl-2-methyl-1-(4-methylbenzyl)aziridine $4 \mathrm{~b}$ (1.27 g, 5 mmol) was dissolved in DMF $(30 \mathrm{~mL})$, after which KSCN $(0.49 \mathrm{~g}$, 1 equiv) was added and the mixture was stirred at $60-70{ }^{\circ} \mathrm{C}$ for $15 \mathrm{~h}$. The reaction mixture was cooled to room temperature, poured into water $(20 \mathrm{~mL})$ and extracted with $\mathrm{CH}_{2} \mathrm{Cl}_{2}(3 \times 20 \mathrm{~mL})$. The combined organic extracts were washed with $\mathrm{H}_{2} \mathrm{O}(2 \times 15 \mathrm{~mL})$ and brine $(20 \mathrm{~mL})$. Drying $\left(\mathrm{MgSO}_{4}\right)$, filtration of the drying agent and evaporation of the solvent afforded 2-methyl-1-(4-methylbenzyl)-2(thiocyanatomethyl)aziridine $\mathbf{8 b}(0.91 \mathrm{~g}, 95 \%)$, which was purified by silica gel column chromatography (hexane/ethyl acetate/triethylamine $1 / 1 / 0.1$ ) to obtain an analytically pure sample. It should be mentioned that aziridines $8 \mathbf{a}-\mathbf{c}$ showed to be rather unstable on silica gel column during the purification process.

1-Benzyl-2-methyl-2-(thiocyanatomethyl)aziridine 8a. Light yellow oil; $R_{\mathrm{f}}=0.43$ (hexane/ethyl acetate/triethylamine 1/1/0.1); Yield, 94\%; isolated yield, $41 \%$ (after purification); ${ }^{1} \mathrm{H}$ NMR $(300 \mathrm{MHz}$, $\left.\mathrm{CDCl}_{3}\right) \delta 1.47(1 \mathrm{H}$ and $3 \mathrm{H}, s), 2.08(1 \mathrm{H}, s), 3.02(\mathrm{H}, d, J=12.9 \mathrm{~Hz})$, $3.14(\mathrm{H}, d, J=12.9 \mathrm{~Hz}), 3.53(\mathrm{H}, d, J=13.8 \mathrm{~Hz}), 3.78(\mathrm{H}, d, J=13.8$ $\mathrm{Hz}), 7.26-7.35(5 \mathrm{H}, m) ;{ }^{13} \mathrm{C}$ NMR $\left(75 \mathrm{MHz}\right.$, ref $\left.=\mathrm{CDCl}_{3}\right) \delta 14.0$ $\left(\mathrm{CH}_{3}\right), 38.8(\mathrm{C}), 40.3\left(\mathrm{CH}_{2}\right), 45.1\left(\mathrm{CH}_{2}\right), 57.1\left(\mathrm{CH}_{2}\right), 113.1(\mathrm{C})$, 
$127.2(\mathrm{CH}), 128.0(2 \times \mathrm{CH}), 128.6(2 \times \mathrm{CH}), 139.3(\mathrm{C})$; IR (neat, $\left.\mathrm{cm}^{-1}\right) \nu_{\mathrm{SCN}}=2152 ; \mathrm{MS} \mathrm{m} / z(\%) 219\left(\mathrm{M}^{+}+1,100\right) ;$ HRMS $\mathrm{m} / \mathrm{z}$ (ESI) calculated for $\mathrm{C}_{12} \mathrm{H}_{14} \mathrm{~N}_{2} \mathrm{~S}[\mathrm{MH}]^{+}$219.0956, found 219.0952 .

2-Methyl-1-(4-methylbenzyl)-2-(thiocyanatomethyl)aziridine $8 b$. Light yellow oil; $R_{\mathrm{f}}=0.44$ (hexane/ethyl acetate/triethylamine 1/1/ 0.1 ); Yield, 95\%; isolated yield, $64 \%$ (after purification); ${ }^{1} \mathrm{H}$ NMR $\left(300 \mathrm{MHz}, \mathrm{CDCl}_{3}\right) \delta 1.46(1 \mathrm{H}$ and $3 \mathrm{H}, s), 2.05(1 \mathrm{H}, s), 2.34(3 \mathrm{H}, s)$, $3.02(\mathrm{H}, d, J=12.7 \mathrm{~Hz}), 3.13(\mathrm{H}, d, J=12.7 \mathrm{~Hz}), 3.49(\mathrm{H}, d, J=13.2$ $\mathrm{Hz}), 3.73(\mathrm{H}, d, J=13.2 \mathrm{~Hz}), 7.13-7.24(4 \mathrm{H}, m) ;{ }^{13} \mathrm{C}$ NMR $(75$ $\mathrm{MHz}$, ref $\left.=\mathrm{CDCl}_{3}\right) \delta 14.0\left(\mathrm{CH}_{3}\right), 21.2\left(\mathrm{CH}_{3}\right), 38.8(\mathrm{C}), 40.2\left(\mathrm{CH}_{2}\right)$, $45.2\left(\mathrm{CH}_{2}\right), 56.8\left(\mathrm{CH}_{2}\right), 113.1(\mathrm{C}), 127.9(2 \times \mathrm{CH}), 129.2(2 \times \mathrm{CH})$, 136.3 (C), 136.8 (C); IR (neat, $\left.\mathrm{cm}^{-1}\right) \nu_{\mathrm{SCN}}=2151$; MS $\mathrm{m} / z$ (\%) 233 $\left(\mathrm{M}^{+}+1,100\right)$; HRMS $m / z$ (ESI) calculated for $\mathrm{C}_{13} \mathrm{H}_{16} \mathrm{~N}_{2} \mathrm{~S}[\mathrm{MH}]^{+}$ 233.1112, found 233.1110 .

1-(4-Methoxybenzyl)-2-methyl-2-(thiocyanatomethyl)aziridine 8c. Light yellow oil; $R_{\mathrm{f}}=0.36$ (hexane/ethyl acetate/triethylamine 1/ $1 / 0.1$ ); Yield, $90 \%$; isolated yield, $37 \%$ (after purification); ${ }^{1} \mathrm{H}$ NMR $\left(300 \mathrm{MHz}, \mathrm{CDCl}_{3}\right) \delta 1.46(1 \mathrm{H}$ and $3 \mathrm{H}, s), 2.04(1 \mathrm{H}, s), 3.00(\mathrm{H}, d, J$ $=12.9 \mathrm{~Hz}), 3.12(\mathrm{H}, d, J=12.9 \mathrm{~Hz}), 3.45(\mathrm{H}, d, J=13.2 \mathrm{~Hz}), 3.71(\mathrm{H}$, $d, J=13.2 \mathrm{~Hz}), 3.81(3 \mathrm{H}, s), 6.86-6.89$ and $7.25-7.28(4 \mathrm{H}, 2 \times m)$; ${ }^{13} \mathrm{C}$ NMR $\left(75 \mathrm{MHz}\right.$, ref $\left.=\mathrm{CDCl}_{3}\right) \delta 14.0\left(\mathrm{CH}_{3}\right), 38.8(\mathrm{C}), 40.2$ $\left(\mathrm{CH}_{2}\right), 45.2\left(\mathrm{CH}_{2}\right), 55.4\left(\mathrm{CH}_{3}\right), 56.5\left(\mathrm{CH}_{2}\right), 113.1(\mathrm{C}), 114.0(2 \times$ $\mathrm{CH}), 129.2(2 \times \mathrm{CH}), 131.4(\mathrm{C}), 158.8(\mathrm{C})$; IR (neat, $\left.\mathrm{cm}^{-1}\right) \nu_{\mathrm{SCN}}=$ 2153; MS $m / z(\%) 249\left(\mathrm{M}^{+}+1,100\right)$; HRMS $m / z$ (ESI) calculated for $\mathrm{C}_{13} \mathrm{H}_{16} \mathrm{~N}_{2} \mathrm{OS}[\mathrm{MH}]^{+} 249,1062$, found 249.1058 .

Synthesis of Azetidine-3-carbonitriles 7d,e. As a representative example, the synthesis of 1-(4-methoxybenzyl)-3-methylazetidine-3carbonitrile $7 \mathbf{e}$ is described here. 2-Bromomethyl-1-(4-methoxybenzyl)-2-methylaziridine $4 \mathrm{c}(1.35 \mathrm{~g}, 5 \mathrm{mmol})$ was dissolved in acetonitrile $(30 \mathrm{~mL})$, after which $\mathrm{KCN}(0.64 \mathrm{~g}, 2$ equiv) was added in small portions and the mixture was heated at reflux temperature for $26 \mathrm{~h}$. The reaction mixture was cooled to room temperature, poured into water $(20 \mathrm{~mL})$ and extracted with $\mathrm{CH}_{2} \mathrm{Cl}_{2}(3 \times 20 \mathrm{~mL})$. The combined organic extracts were washed with $\mathrm{H}_{2} \mathrm{O}(2 \times 15 \mathrm{~mL})$ and brine $(20 \mathrm{~mL})$. Drying $\left(\mathrm{MgSO}_{4}\right)$, filtration of the drying agent and evaporation of the solvent afforded 1-(4-methoxybenzyl)-3-methylazetidine-3-carbonitrile 7 e $(0.96 \mathrm{~g}, 95 \%)$, which was purified by silica gel column chromatography (dichloromethane/methanol 10/1) to obtain an analytically pure sample.

3-Methyl-1-(4-methylbenzyl)azetidine-3-carbonitrile 7d. Yellow oil; $R_{\mathrm{f}}=0.28$ (dichloromethane); Yield, $96 \%$; isolated yield, $88 \%$ (after purification); ${ }^{1} \mathrm{H}$ NMR $\left(300 \mathrm{MHz}, \mathrm{CDCl}_{3}\right) \delta 1.64(3 \mathrm{H}, s), 2.33(3 \mathrm{H}$, s), $3.19(2 \mathrm{H}, d, J=6.9 \mathrm{~Hz}), 3.48(2 \mathrm{H}, d, J=6.9 \mathrm{~Hz}), 3.58(2 \mathrm{H}, s)$, $7.04-7.24(4 \mathrm{H}, m) ;{ }^{13} \mathrm{C}$ NMR $\left(75 \mathrm{MHz}\right.$, ref $\left.=\mathrm{CDCl}_{3}\right) \delta 21.2\left(\mathrm{CH}_{3}\right)$, $22.9\left(\mathrm{CH}_{3}\right), 27.1(\mathrm{C}), 62.5\left(\mathrm{CH}_{2}\right), 63.4\left(2 \times \mathrm{CH}_{2}\right), 123.5(\mathrm{C}), 128.4$ $(2 \times \mathrm{CH}), 129.2(2 \times \mathrm{CH}), 133.9(\mathrm{C}), 137.1(\mathrm{C})$; IR (neat, $\left.\mathrm{cm}^{-1}\right) \nu_{\mathrm{CN}}$ $=2238 ; \mathrm{MS} m / z(\%) 201\left(\mathrm{M}^{+}+1,100\right) ; \mathrm{HRMS} m / z$ (ESI) calculated for $\mathrm{C}_{13} \mathrm{H}_{16} \mathrm{~N}_{2}[\mathrm{MH}]^{+}$201.1392, found 201.1389.

1-(4-Methoxybenzyl)-3-methylazetidine-3-carbonitrile 7e. Yellow oil; $R_{\mathrm{f}}=0.60$ (dichloromethane/methanol 10/1); Yield, 95\%; isolated yield, $89 \%$ (after purification); ${ }^{1} \mathrm{H}$ NMR $\left(300 \mathrm{MHz}, \mathrm{CDCl}_{3}\right) \delta 1.64$ $(3 \mathrm{H}, s), 3.18(2 \mathrm{H}, d, J=7.2 \mathrm{~Hz}), 3.48(2 \mathrm{H}, d, J=7.2 \mathrm{~Hz}), 3.56(2 \mathrm{H}$, s), $3.80(3 \mathrm{H}, s), 6.84-6.87$ and $7.16-7.19(4 \mathrm{H}, 2 \times m) ;{ }^{13} \mathrm{C} \mathrm{NMR}(75$ $\left.\mathrm{MHz}, \mathrm{CDCl}_{3}\right) \delta 22.7\left(\mathrm{CH}_{3}\right), 27.0(\mathrm{C}), 55.3\left(\mathrm{CH}_{3}\right), 62.1\left(\mathrm{CH}_{2}\right), 63.2$ $\left(2 \times \mathrm{CH}_{2}\right), 113.8(2 \times \mathrm{CH}), 123.4(\mathrm{C}), 128.9(\mathrm{C}), 129.6(2 \times \mathrm{CH})$, 158.9 (C); IR (neat, $\left.\mathrm{cm}^{-1}\right) \nu_{\mathrm{CN}}=2238$; MS $m / z(\%) 217\left(\mathrm{M}^{+}+1\right.$, 100); HRMS $m / z$ (ESI) calculated for $\mathrm{C}_{13} \mathrm{H}_{16} \mathrm{~N}_{2} \mathrm{O}[\mathrm{MH}]^{+}$217.1341, found 217.1340 .

Synthesis of 2-Cyanomethyl-2-methylaziridines $8 \mathrm{~d}$,e. As a representative example, the synthesis of 2-cyanomethyl-2-methyl-1-(4methylbenzyl)aziridine $\mathbf{8 d}$ is described here. 2-Bromomethyl-2methyl-1-(4-methylbenzyl)aziridine $4 \mathrm{~b}(1.27 \mathrm{~g}, 5 \mathrm{mmol})$ was dissolved in DMF $(30 \mathrm{~mL})$, after which $\mathrm{KCN}(0.33 \mathrm{~g}, 1$ equiv) was added and the mixture was stirred at $50-60{ }^{\circ} \mathrm{C}$ for $16 \mathrm{~h}$. The reaction mixture was cooled to room temperature, poured into water $(20 \mathrm{~mL})$ and extracted with $\mathrm{Et}_{2} \mathrm{O}(3 \times 20 \mathrm{~mL})$. The combined organic extracts were washed with $\mathrm{H}_{2} \mathrm{O}(2 \times 15 \mathrm{~mL})$ and brine $(20 \mathrm{~mL})$. Drying $\left(\mathrm{MgSO}_{4}\right)$, filtration of the drying agent and evaporation of the solvent afforded 2cyanomethyl-2-methyl-1-(4-methylbenzyl)aziridine 8d (0.85 g, 85\%), which was purified by silica gel column chromatography (hexane/ethyl acetate $1 / 1$ ) to obtain an analytically pure sample. It should be mentioned that aziridines 8d,e showed to be rather unstable on silica gel column during the purification process.

2-Cyanomethyl-2-methyl-1-(4-methylbenzyl)aziridine 8d. Yellow oil; $R_{\mathrm{f}}=0.29$ (hexane/ethyl acetate $1 / 1$ ); Yield, $85 \%$; isolated yield, $36 \%$ (after purification); ${ }^{1} \mathrm{H}$ NMR $\left(300 \mathrm{MHz}, \mathrm{CDCl}_{3}\right) \delta 1.39(1 \mathrm{H}, s)$, $1.43(3 \mathrm{H}, s), 1.96(1 \mathrm{H}, s), 2.33(3 \mathrm{H}, s), 2.40(\mathrm{H}, d, J=16.8 \mathrm{~Hz}), 2.49$ $(\mathrm{H}, d, J=16.8 \mathrm{~Hz}), 3.52(\mathrm{H}, d, J=13.8 \mathrm{~Hz}), 3.69(\mathrm{H}, d, J=13.8 \mathrm{~Hz})$, 7.13-7.25 $(4 \mathrm{H}, m) ;{ }^{13} \mathrm{C}$ NMR $\left(75 \mathrm{MHz}\right.$, ref $\left.=\mathrm{CDCl}_{3}\right) \delta 14.8\left(\mathrm{CH}_{3}\right)$, $21.2\left(\mathrm{CH}_{3}\right), 29.4\left(\mathrm{CH}_{2}\right), 36.7(\mathrm{C}), 39.4\left(\mathrm{CH}_{2}\right), 56.7\left(\mathrm{CH}_{2}\right), 117.8$ (C), $127.7(2 \times \mathrm{CH}), 129.3(2 \times \mathrm{CH}), 136.4(\mathrm{C}), 136.8$ (C); IR (neat, $\left.\mathrm{cm}^{-1}\right) \nu_{\mathrm{CN}}=2250 ; \mathrm{MS} m / z(\%) 201\left(\mathrm{M}^{+}+1,100\right) ;$ HRMS $\mathrm{m} / z$ (ESI) calculated for $\mathrm{C}_{13} \mathrm{H}_{16} \mathrm{~N}_{2}[\mathrm{MH}]^{+} 201.1392$, found 201.1386 .

2-Cyanomethyl-1-(4-methoxybenzyl)-2-methylaziridine 8e. Yellow oil; $R_{\mathrm{f}}=0.21$ (hexane/ethyl acetate $1 / 1$ ); Yield, $89 \%$; isolated yield, $42 \%$ (after purification); ${ }^{1} \mathrm{H}$ NMR $\left(300 \mathrm{MHz}, \mathrm{CDCl}_{3}\right) \delta 1.39$ $(1 \mathrm{H}, s), 1.44(3 \mathrm{H}, s), 1.96(1 \mathrm{H}, s), 2.41(\mathrm{H}, d, J=17.1 \mathrm{~Hz}), 2.49(\mathrm{H}, d$, $J=17.1 \mathrm{~Hz}), 3.49(\mathrm{H}, d, J=13.5 \mathrm{~Hz}), 3.68(\mathrm{H}, d, J=13.5 \mathrm{~Hz}), 3.81$ $(3 \mathrm{H}, s), 6.86-6.90$ and $7.26-7.28(4 \mathrm{H}, 2 \times \mathrm{m}) ;{ }^{13} \mathrm{C} \mathrm{NMR}(75 \mathrm{MHz}$, ref $\left.=\mathrm{CDCl}_{3}\right) \delta 14.8\left(\mathrm{CH}_{3}\right), 29.4\left(\mathrm{CH}_{2}\right), 36.7(\mathrm{C}), 39.4\left(\mathrm{CH}_{2}\right), 55.4$ $\left(\mathrm{CH}_{3}\right), 56.4\left(\mathrm{CH}_{2}\right), 114.0(2 \times \mathrm{CH}), 117.8(\mathrm{C}), 128.9(2 \times \mathrm{CH}), 131.5$ (C), 158.8 (C); IR (neat, $\left.\mathrm{cm}^{-1}\right) \nu_{\mathrm{CN}}=2249 ; \mathrm{MS} m / z(\%) 217\left(\mathrm{M}^{+}+\right.$ $1,100)$; HRMS $m / z$ (ESI) calculated for $\mathrm{C}_{13} \mathrm{H}_{16} \mathrm{~N}_{2} \mathrm{O}[\mathrm{MH}]^{+}$ 217.1341 , found 217.1344

Synthesis of 3-Methyl-3-phenoxyazetidines 7f,g. As a representative example, the synthesis of 1-(4-methoxybenzyl)-3methyl-3-phenoxyazetidine $7 \mathrm{~g}$ is described here. 2-Bromomethyl-1(4-methoxybenzyl)-2-methylaziridine $4 \mathrm{c}(1.35 \mathrm{~g}, 5 \mathrm{mmol})$ was added to a mixture of phenol (1.04 g, 2.2 equiv) and $\mathrm{K}_{2} \mathrm{CO}_{3}(3.46 \mathrm{~g}, 5$ equiv) dissolved in acetonitrile $(30 \mathrm{~mL})$, and the resulting suspension was heated at reflux temperature for $24 \mathrm{~h}$. The reaction mixture was cooled to room temperature, poured into a $\mathrm{NaOH}$ solution $(30 \mathrm{~mL}, 0.5 \mathrm{M})$ and extracted with $\mathrm{CH}_{2} \mathrm{Cl}_{2}(3 \times 20 \mathrm{~mL})$. The combined organic extracts were washed with $\mathrm{H}_{2} \mathrm{O}(2 \times 15 \mathrm{~mL})$ and brine $(20 \mathrm{~mL})$. Drying $\left(\mathrm{MgSO}_{4}\right)$, filtration of the drying agent and evaporation of the solvent afforded a mixture of 1-(4-methoxybenzyl)-3-methyl-3phenoxyazetidine $7 \mathrm{~g}$ and 1-(4-methoxybenzyl)-2-methyl-2(phenoxymethyl)aziridine $8 \mathrm{~g}(7 \mathrm{~g} / 8 \mathrm{~g}=$ ratio $67 / 33)$, from which 1 (4-methoxybenzyl)-3-methyl-3-phenoxyazetidine $7 \mathrm{~g}(0.93 \mathrm{~g}, 65 \%)$ was isolated in pure form by silica gel column chromatography (petroleum ether/ethyl acetate 4/1).

3-Methyl-1-(4-methylbenzyl)-3-phenoxyazetidine 7f. Yellow oil; $R_{\mathrm{f}}=0.25$ (petroleum ether/ethyl acetate 4/1); Yield, $47 \%$; isolated yield, $37 \%$ (after purification); ${ }^{1} \mathrm{H}$ NMR $\left(300 \mathrm{MHz}, \mathrm{CDCl}_{3}\right) \delta 1.60$ $(3 \mathrm{H}, s), 2.33(3 \mathrm{H}, s), 3.29(2 \mathrm{H}, d, J=8.3 \mathrm{~Hz}), 3.55(2 \mathrm{H}, d, J=8.3$ $\mathrm{Hz}), 3.66(2 \mathrm{H}, s), 6.67-6.70,6.91-6.95$ and $7.11-7.31(9 \mathrm{H}, 3 \times m)$; ${ }^{13} \mathrm{C}$ NMR $\left(75 \mathrm{MHz}\right.$, ref $\left.=\mathrm{CDCl}_{3}\right) \delta 21.2\left(\mathrm{CH}_{3}\right), 22.0\left(\mathrm{CH}_{3}\right), 63.4$ $\left(\mathrm{CH}_{2}\right), 66.3\left(2 \times \mathrm{CH}_{2}\right), 73.6(\mathrm{C}), 116.8(2 \times \mathrm{CH}), 120.9(\mathrm{CH}), 128.5$ (2× CH), $129.1(2 \times \mathrm{CH}), 129.5(2 \times \mathrm{CH}), 136.8(\mathrm{C}), 137.0(\mathrm{C})$, 155.3 (C); IR (neat, $\mathrm{cm}^{-1}$ ) $\nu_{\max }=2927,2838,1599,1587,1514,1494$, 1456, 1241, 1223, 1170, 1034, 959, 803, 752, 692; MS $m / z$ (\%) 268 $\left(\mathrm{M}^{+}+1,100\right)$; HRMS $\mathrm{m} / z$ (ESI) calculated for $\mathrm{C}_{18} \mathrm{H}_{21} \mathrm{NO}[\mathrm{MH}]^{+}$ 268.1701 , found 268.1698 .

1-(4-Methoxybenzyl)-3-methyl-3-phenoxyazetidine 7g. Yellow oil; $R_{f}=0.07$ (petroleum ether/ethyl acetate 4/1); Yield, 65\%; isolated yield, $42 \%$ (after purification); ${ }^{1} \mathrm{H}$ NMR $\left(300 \mathrm{MHz}, \mathrm{CDCl}_{3}\right) \delta$ $1.67(3 \mathrm{H}, s), 3.28(2 \mathrm{H}, d, J=8.3 \mathrm{~Hz}), 3.53(2 \mathrm{H}, d, J=8.3 \mathrm{~Hz}), 3.63$ $(2 \mathrm{H}, s), 3.79(3 \mathrm{H}, s), 6.67-6.70,6.84-6.95$ and $7.20-7.26(9 \mathrm{H}, 3 \times$ $m) ;{ }^{13} \mathrm{C}$ NMR $\left(75 \mathrm{MHz}\right.$, ref $\left.=\mathrm{CDCl}_{3}\right) \delta 22.0\left(\mathrm{CH}_{3}\right), 55.3\left(\mathrm{CH}_{3}\right), 63.0$ $\left(\mathrm{CH}_{2}\right), 66.2\left(2 \times \mathrm{CH}_{2}\right), 73.6(\mathrm{C}), 113.8(2 \times \mathrm{CH}), 116.8(2 \times \mathrm{CH})$, $121.0(\mathrm{CH}), 129.5(2 \times \mathrm{CH}), 129.8(2 \times \mathrm{CH}), 130.2(\mathrm{C}), 155.3(\mathrm{C})$, 158.9 (C); IR (neat, $\mathrm{cm}^{-1}$ ) $\nu_{\max }=2932,2834,2364,1611,1586,1511$, $1493,1242,1223,1204,1171,1034,958,818,752,693$; MS $m / z$ (\%) $284\left(\mathrm{M}^{+}+1,100\right)$; HRMS $m / z$ (ESI) calculated for $\mathrm{C}_{18} \mathrm{H}_{21} \mathrm{NO}_{2}$ $[\mathrm{MH}]^{+} 284.1651$, found 284.1645 .

Synthesis of 2-Methyl-2-(phenoxymethyl)aziridines $\mathbf{8 f , g}$. As a representative example, the synthesis of 1-(4-methoxybenzyl)-2methyl-2-(phenoxymethyl)aziridine $\mathbf{8 g}$ is described here. 2-Bromomethyl-1-(4-methoxybenzyl)-2-methylaziridine $4 \mathrm{c}(1.35 \mathrm{~g}, 5 \mathrm{mmol})$ was added to a mixture of phenol (1.04 g, 2.2 equiv) and $\mathrm{K}_{2} \mathrm{CO}_{3}(3.46$ 
g, 5 equiv) in DMF $(30 \mathrm{~mL})$, and the resulting suspension was heated at $50{ }^{\circ} \mathrm{C}$ for $14 \mathrm{~h}$. The reaction mixture was cooled to room temperature, poured into a $\mathrm{NaOH}$ solution $(30 \mathrm{~mL}, 0.5 \mathrm{M})$ and extracted with $\mathrm{Et}_{2} \mathrm{O}(3 \times 20 \mathrm{~mL})$. The combined organic extracts were washed with $\mathrm{H}_{2} \mathrm{O}(2 \times 15 \mathrm{~mL})$ and brine $(20 \mathrm{~mL})$. Drying $\left(\mathrm{MgSO}_{4}\right)$, filtration of the drying agent and evaporation of the solvent afforded 1(4-methoxybenzyl)-2-methyl-2-(phenoxymethyl)aziridine $8 \mathrm{~g}$ (1.27 g, $76 \%$ ), which was purified by silica gel column chromatography (petroleum ether/ethyl acetate $4 / 1$ ) to obtain an analytically pure sample.

2-Methyl-1-(4-methylbenzyl)-2-(phenoxymethyl)aziridine 8f. Yellow oil; $R_{\mathrm{f}}=0.17$ (petroleum ether/ethyl acetate 4/1); Yield, $85 \%$; isolated yield, $70 \%$ (after purification); ${ }^{1} \mathrm{H}$ NMR $\left(300 \mathrm{MHz}, \mathrm{CDCl}_{3}\right) \delta$ $1.42(1 \mathrm{H}, s), 1.44(3 \mathrm{H}, s), 2.00(1 \mathrm{H}, s), 2.34(3 \mathrm{H}, s), 3.60(\mathrm{H}, d, J=$ $14.0 \mathrm{~Hz}), 3.73(\mathrm{H}, d, J=14.0 \mathrm{~Hz}), 3.75(\mathrm{H}, d, J=9.8 \mathrm{~Hz}), 3.90(\mathrm{H}, d$, $J=9.8 \mathrm{~Hz}), 6.88-6.96$ and $7.11-7.30(9 \mathrm{H}, 2 \times m) ;{ }^{13} \mathrm{C} \mathrm{NMR}(75$ $\mathrm{MHz}$, ref $\left.=\mathrm{CDCl}_{3}\right) \delta 13.0\left(\mathrm{CH}_{3}\right), 21.2\left(\mathrm{CH}_{3}\right), 38.9\left(\mathrm{CH}_{2}\right), 39.2(\mathrm{C})$, $56.3\left(\mathrm{CH}_{2}\right), 75.8\left(\mathrm{CH}_{2}\right), 114.7(2 \times \mathrm{CH}), 120.8(\mathrm{CH}), 127.7(2 \times$ $\mathrm{CH}), 129.1(2 \times \mathrm{CH}), 129.5(2 \times \mathrm{CH}), 136.4(\mathrm{C}), 137.0(\mathrm{C}), 159.1$ (C); IR (neat, $\mathrm{cm}^{-1}$ ) $\nu_{\max }=3030,2922,1599,1586,1495,1456,1241$, 1171, 1034, 1020, 798, 752, 691; MS $m / z(\%) 268\left(\mathrm{M}^{+}+1,100\right)$; HRMS $m / z$ (ESI) calculated for $\mathrm{C}_{18} \mathrm{H}_{21} \mathrm{NO}[\mathrm{MH}]^{+} 268.1701$, found 268.1689.

1-(4-Methoxybenzyl)-2-methyl-2-(phenoxymethyl)aziridine $8 g$. Yellow oil; $R_{\mathrm{f}}=0.31$ (petroleum ether/ethyl acetate 4/1); Yield, 90\%; isolated yield, $76 \%$ (after purification); ${ }^{1} \mathrm{H}$ NMR (300 $\mathrm{MHz}$, $\left.\mathrm{CDCl}_{3}\right) \delta 1.41(1 \mathrm{H}, s), 1.45(3 \mathrm{H}, s), 2.00(1 \mathrm{H}, s), 3.56(\mathrm{H}, d, J=13.8$ $\mathrm{Hz}), 3.71(\mathrm{H}, d, J=13.8 \mathrm{~Hz}), 3.76(\mathrm{H}, d, J=9.4 \mathrm{~Hz}), 3.81(3 \mathrm{H}, s)$, $3.89(\mathrm{H}, d, J=9.4 \mathrm{~Hz}), 6.84-6.96$ and $7.24-7.33(9 \mathrm{H}, 2 \times m) ;{ }^{13} \mathrm{C}$ $\operatorname{NMR}\left(75 \mathrm{MHz}\right.$, ref $\left.=\mathrm{CDCl}_{3}\right) \delta 13.0\left(\mathrm{CH}_{3}\right), 38.9\left(\mathrm{CH}_{2}\right), 39.2(\mathrm{C})$, $55.4\left(\mathrm{CH}_{3}\right), 56.0\left(\mathrm{CH}_{2}\right), 75.9\left(\mathrm{CH}_{2}\right), 113.9(2 \times \mathrm{CH}), 114.8(2 \times \mathrm{CH})$, $120.8(\mathrm{CH}), 128.9(2 \times \mathrm{CH}), 129.5(2 \times \mathrm{CH}), 132.2(\mathrm{C}), 158.6(\mathrm{C})$, 159.1 (C); IR (neat, $\mathrm{cm}^{-1}$ ) $\nu_{\max }=3038,2930,2835,1599,1586,1511$, 1496, 1463, 1300, 1241, 1172, 1033, 819, 753, 691; MS m/z (\%) 284 $\left(\mathrm{M}^{+}+1,100\right)$; HRMS $m / z$ (ESI) calculated for $\mathrm{C}_{18} \mathrm{H}_{21} \mathrm{NO}_{2}[\mathrm{MH}]^{+}$ 284.1651, found 284.1659.

Synthesis of 3-Acetoxy-3-methylazetidines 7h,i. As a representative example, the synthesis of 3-acetoxy-3-methyl-1-(4methylbenzyl)azetidine $7 \mathrm{~h}$ is described here. 2-Bromomethyl-2methyl-1-(4-methylbenzyl)aziridine $4 \mathrm{~b}(1.27 \mathrm{~g}, 5 \mathrm{mmol})$ was dissolved in acetonitrile $(30 \mathrm{~mL})$, after which $\mathrm{NaOAc}(0.45 \mathrm{~g}, 1.1$ equiv) was added and the mixture was heated at reflux temperature for $24 \mathrm{~h}$. The reaction mixture was cooled to room temperature, poured into water $(20 \mathrm{~mL})$ and extracted with $\mathrm{CH}_{2} \mathrm{Cl}_{2}(3 \times 20 \mathrm{~mL})$. The combined organic extracts were washed with $\mathrm{H}_{2} \mathrm{O}(2 \times 15 \mathrm{~mL})$ and brine $(20$ $\mathrm{mL})$. Drying $\left(\mathrm{MgSO}_{4}\right)$, filtration of the drying agent and evaporation of the solvent afforded 3-acetoxy-1-(4-methylbenzyl)-3-methylazetidine $7 \mathrm{~h}(1.10 \mathrm{~g}, 87 \%)$, which was purified by silica gel column chromatography (petroleum ether/ethyl acetate 4/1) to obtain an analytically pure sample.

3-Acetoxy-3-methyl-1-(4-methylbenzyl)azetidine 7h. Yellow oil; $R_{\mathrm{f}}=0.11$ (petroleum ether/ethyl acetate 4/1); Yield, 95\%; isolated yield, $87 \%$ (after purification); ${ }^{1} \mathrm{H}$ NMR $\left(300 \mathrm{MHz}, \mathrm{CDCl}_{3}\right) \delta 1.64$ $(3 \mathrm{H}, s), 2.01(3 \mathrm{H}, s), 2.32(3 \mathrm{H}, s), 3.13(2 \mathrm{H}, d, J=9.1 \mathrm{~Hz}), 3.46(2 \mathrm{H}$, $d, J=9.1 \mathrm{~Hz}), 3.61(2 \mathrm{H}, s), 7.09-7.17(4 \mathrm{H}, m) ;{ }^{13} \mathrm{C} \mathrm{NMR}(75 \mathrm{MHz}$, ref $\left.=\mathrm{CDCl}_{3}\right) \delta 21.2\left(\mathrm{CH}_{3}\right), 21.6\left(\mathrm{CH}_{3}\right), 22.7\left(\mathrm{CH}_{3}\right), 63.3\left(\mathrm{CH}_{2}\right), 65.8$ $\left(2 \times \mathrm{CH}_{2}\right), 74.3(\mathrm{C}), 128.5(2 \times \mathrm{CH}), 129.1(2 \times \mathrm{CH}), 135.0(\mathrm{C})$, 136.8 (C), 169.7 (C); IR (neat, $\mathrm{cm}^{-1}$ ) $\nu_{\mathrm{CO}}=1737$; MS $\mathrm{m} / z$ (\%) 234 $\left(\mathrm{M}^{+}+1,100\right)$; HRMS $m / z$ (ESI) calculated for $\mathrm{C}_{14} \mathrm{H}_{19} \mathrm{NO}_{2}[\mathrm{MH}]^{+}$ 234.1494, found 234.1490.

3-Acetoxy-1-(4-methoxybenzyl)-3-methylazetidine 7i. Yellow oil; $R_{\mathrm{f}}=0.06$ (hexane/ethyl acetate $2 / 1$ ); Yield, $92 \%$; isolated yield, $84 \%$ (after purification); ${ }^{1} \mathrm{H}$ NMR $\left(300 \mathrm{MHz}, \mathrm{CDCl}_{3}\right) \delta 1.64(3 \mathrm{H}, s), 2.02$ $(3 \mathrm{H}, s), 3.12(2 \mathrm{H}, d, J=9.4 \mathrm{~Hz}), 3.45(2 \mathrm{H}, d, J=9.4 \mathrm{~Hz}), 3.59(2 \mathrm{H}$, s), $3.79(3 \mathrm{H}, s), 6.83-6.86$ and $7.17-7.20(4 \mathrm{H}, 2 \times m) ;{ }^{13} \mathrm{C} \mathrm{NMR}(75$ $\mathrm{MHz}$, ref $\left.=\mathrm{CDCl}_{3}\right) \delta 21.6\left(\mathrm{CH}_{3}\right), 22.6\left(\mathrm{CH}_{3}\right), 55.3\left(\mathrm{CH}_{3}\right), 62.9$ $\left(\mathrm{CH}_{2}\right), 65.6\left(2 \times \mathrm{CH}_{2}\right), 74.2(\mathrm{C}), 113.8(2 \times \mathrm{CH}), 129.7(2 \times \mathrm{CH})$, 130.0 (C), 158.8 (C), 169.8 (C); IR (neat, $\mathrm{cm}^{-1}$ ) $\nu_{\mathrm{CO}}=1736$; MS m/ $z$ (\%) $250\left(\mathrm{M}^{+}+1,100\right)$; HRMS $m / z$ (ESI) calculated for $\mathrm{C}_{14} \mathrm{H}_{19} \mathrm{NO}_{3}$ $[\mathrm{MH}]^{+} 250.1443$, found 250.1444 .
Synthesis of 2-Acetoxymethyl-2-methylaziridines $8 \mathrm{~h}, \mathrm{i}$. As a representative example, the synthesis of 2-acetoxymethyl-2-methyl-1(4-methylbenzyl)aziridine $\mathbf{8 h}$ is described here. 2-Bromomethyl-2methyl-1-(4-methylbenzyl)aziridine $4 \mathrm{~b}(1.27 \mathrm{~g}, 5 \mathrm{mmol})$ was dissolved in DMSO $(30 \mathrm{~mL})$, after which $\mathrm{NaOAc}(0.45 \mathrm{~g}, 1.1$ equiv) was added and the mixture was stirred at room temperature for 5 days. The reaction mixture was poured into water $(20 \mathrm{~mL})$ and extracted with $\mathrm{Et}_{2} \mathrm{O}(3 \times 20 \mathrm{~mL})$. The combined organic extracts were washed with $\mathrm{H}_{2} \mathrm{O}(2 \times 15 \mathrm{~mL})$ and brine $(20 \mathrm{~mL})$. Drying $\left(\mathrm{MgSO}_{4}\right)$, filtration of the drying agent and evaporation of the solvent afforded a mixture of 3-acetoxy-3-methyl-1-(4-methylbenzyl)azetidine $7 \mathrm{~h}$ and 2-acetoxymethyl-2-methyl-1-(4-methylbenzyl)aziridine $8 \mathbf{h}(7 \mathbf{h} / 8 \mathbf{h}=$ ratio $20 /$ $80)$, from which 2-acetoxymethyl-2-methyl-1-(4-methylbenzyl)aziridine $\mathbf{8 h}$ could not be isolated in completely pure form by silica gel column chromatography (petroleum ether/ethyl acetate 4/1). No accurate elemental analyses or HRMS analyses could be performed on 2 -(acetoxymethyl)aziridines.

2-Acetoxymethyl-2-methyl-1-(4-methylbenzyl)aziridine 8h. Yellow oil; $R_{\mathrm{f}}=0.22$ (petroleum ether/ethyl acetate 4/1); ${ }^{1} \mathrm{H}$ NMR $(300$ $\left.\mathrm{MHz}, \mathrm{CDCl}_{3}\right) \delta 1.31(3 \mathrm{H}, s), 1.35(1 \mathrm{H}, s), 1.95(1 \mathrm{H}, s), 2.07(3 \mathrm{H}, s)$, $2.33(3 \mathrm{H}, s), 3.64(2 \mathrm{H}, s), 3.89(\mathrm{H}, d, J=11.3 \mathrm{~Hz}), 4.01(\mathrm{H}, d, J=11.3$ $\mathrm{Hz}), 7.12-7.15$ and $7.25-7.27(4 \mathrm{H}, 2 \times m) ;{ }^{13} \mathrm{C}$ NMR $(75 \mathrm{MHz}$, ref $\left.=\mathrm{CDCl}_{3}\right) \delta 12.9\left(\mathrm{CH}_{3}\right), 21.0\left(\mathrm{CH}_{3}\right), 21.2\left(\mathrm{CH}_{3}\right), 38.3(\mathrm{C}), 38.6$ $\left(\mathrm{CH}_{2}\right), 56.3\left(\mathrm{CH}_{2}\right), 71.9\left(\mathrm{CH}_{2}\right), 127.6(2 \times \mathrm{CH}), 129.1(2 \times \mathrm{CH})$, 136.4 (C), 136.9 (C), $171.1(\mathrm{C}) ; \mathrm{IR}\left(\right.$ neat, $\left.\mathrm{cm}^{-1}\right) \nu_{\mathrm{CO}}=1737$; MS $\mathrm{m} /$ $z(\%) 234\left(\mathrm{M}^{+}+1,100\right)$.

2-Acetoxymethyl-1-(4-methoxybenzyl)-2-methylaziridine 8i. Yellow oil; $R_{\mathrm{f}}=0.21$ (petroleum ether/ethyl acetate $\left.1 / 1\right) ;{ }^{1} \mathrm{H}$ NMR $(300$ $\left.\mathrm{MHz}, \mathrm{CDCl}_{3}\right) \delta 1.31(3 \mathrm{H}, s), 1.34(1 \mathrm{H}, s), 1.94(1 \mathrm{H}, s), 2.07(3 \mathrm{H}, s)$, $3.61(2 \mathrm{H}, s), 3.80(3 \mathrm{H}, s), 3.88(\mathrm{H}, d, J=11.3 \mathrm{~Hz}), 4.00(\mathrm{H}, d, J=11.3$ $\mathrm{Hz}), 6.85-6.88$ and $7.26-7.31(4 \mathrm{H}, 2 \times m) ;{ }^{13} \mathrm{C}$ NMR (75 MHz, ref $\left.=\mathrm{CDCl}_{3}\right) \delta 12.9\left(\mathrm{CH}_{3}\right), 21.0\left(\mathrm{CH}_{3}\right), 38.3(\mathrm{C}), 38.5\left(\mathrm{CH}_{2}\right), 55.4$ $\left(\mathrm{CH}_{3}\right), 56.0\left(\mathrm{CH}_{2}\right), 71.8\left(\mathrm{CH}_{2}\right), 113.8(2 \times \mathrm{CH}), 128.8(2 \times \mathrm{CH})$, 132.1 (C), $158.6(\mathrm{C}), 171.1(\mathrm{C}) ; \mathrm{IR}\left(\right.$ neat, $\left.\mathrm{cm}^{-1}\right) \nu_{\mathrm{CO}}=1736$; MS $\mathrm{m} /$ $z(\%) 250\left(\mathrm{M}^{+}+1,100\right)$.

\section{ASSOCIATED CONTENT}

\section{Supporting Information}

Spectra $\left({ }^{1} \mathrm{H}\right.$ and ${ }^{13} \mathrm{C}$ NMR) of $6 \mathbf{a}, 6 \mathbf{c}, 7 \mathbf{a}-\mathbf{i}, 8 \mathbf{a}-\mathbf{i}$. Cartesian coordinates and energy of the optimized geometries (B3LYP/ $6-31+G(d, p))$ for coordination of the bicyclic aziridinium 5 , $\mathrm{CN}^{-}, \mathrm{SCN}^{-}$and $\mathrm{Br}^{-}$by an increasing number of DMF or $\mathrm{MeCN}$ molecules. Coordination solvation energies (CSE's) (MPW1K/6-31++G(d,p)//B3LYP/6-31+G(d,p)) for coordination of the bicyclic aziridinium ions $5, \mathrm{CN}^{-}, \mathrm{SCN}^{-}$and $\mathrm{Br}^{-}$ by an increasing number of DMF or MeCN molecules. This material is available free of charge via the Internet at http:// pubs.acs.org.

\section{AUTHOR INFORMATION}

\section{Corresponding Author}

*veronique.vanspeybroeck@UGent.be; matthias.dhooghe@ UGent.be; norbert.dekimpe@UGent.be

\section{Notes}

The authors declare no competing financial interest.

\section{ACKNOWLEDGMENTS}

This work was supported by the Research Foundation-Flanders (FWO-Vlaanderen), the Research Board of Ghent University (BOF-GOA) and the IAP-BELSPO program in the frame of IAP 6/27. Computational resources and services used in this work were provided by Ghent University.

\section{REFERENCES}

(1) (a) Lindstrom, U. M.; Somfai, P. Synthesis 1998, 109. (b) Zwanenburg, B.; Ten Holte, P. Top. Curr. Chem. 2001, 93. 
(c) Watson, I. D. G.; Yu, L.; Yudin, A. K. Acc. Chem. Res. 2006, 39, 194. (d) Fantauzzi, S.; Gallo, E.; Caselli, A.; Piangiolino, C.; Ragaini, F.; Re, N.; Cenini, S. Chem.-Eur. J. 2009, 15, 1241. (e) Tsang, S. D.; Yang, S.; Alphonse, F.-A.; Yudin, A. K. Chem.-Eur. J. 2008, 14, 886. (f) Lowden, P. A. S. Org. Synth. 2006, 399. (g) Dahanukar, V. H.; Zavialov, L. A. Curr. Opin. Drug Disc. 2002, 5, 918. (h) Ismail, F. M. D.; Levitsky, D. O.; Dembitsky, V. M. Eur. J. Med. Chem. 2009, 44, 3373. (i) Stamm, H. J. Prakt. Chem. 1999, 341, 319. (j) Sweeney, J. B. In Science of Synthesis; Enders, D., Ed.; Georg Thieme Verlag: Stuttgart, 2008; Vol. 40a, pp 643-772. (k) Pellissier, H. Tetrahedron 2010, 66, 1509 .

(2) (a) Lu, P. Tetrahedron 2010, 66, 2549. (b) Hu, X. E. Tetrahedron 2004, 60, 2701. (c) Sweeney, J. B. Chem. Soc. Rev. 2002, 31, 247. (d) McCoull, W.; Davis, F. A. Synthesis 2000, 1347. (e) Singh, G. S.; D'hooghe, M.; De Kimpe, N. Chem. Rev. 2007, 107, 2080. (f) Tanner, D. Angew. Chem., Int. Ed. Engl. 1994, 33, 599. (g) Osborn, H. M. I.; Sweeney, J. B. Tetrahedron: Asymmetry 1997, 8, 1693. (h) Zwanenburg, B.; Ten Holte, I. In Stereoselective Heterocyclic chemistry III; Metz, P., Ed.; Springer: Berlin, 2001; pp 93-124.

(3) (a) Couty, F.; Evano, G. Synlett 2009, 3053. (b) Couty, F. Sci. Synth. 2009, 773. (c) Couty, F.; Durrat, F.; Evano, G. Targets Heterocycl. Syst. 2005, 9, 186. (d) Couty, F.; Evano, G. Org. Prep. Proced. Int. 2006, 38, 427. (e) Abbaspour Tehrani, K.; De Kimpe, N. Curr. Org. Chem. 2009, 13, 854. (f) Leng, D.-H.; Wang, D.-X.; Pan, J.; Huang, Z.-T.; Wang, M.-X. J. Org. Chem. 2009, 74, 6077. (g) Yadav, L. D. S.; Srivastava, V. P.; Patel, R. Tetrahedron Lett. 2008, 49, 5652; (h) Mutti, S.; Lavigne, M.; Grondard, L.; Malpart, J.; Rieke-Zapp, J. R.; Crocq, V. PCT Int. Appl. 2006, WO Patent 2006040465; Chem. Abstr. 2006, 144, 412348. (i) Hayashi, K.; Hiki, S.; Kumagai, T.; Nagao, Y. Heterocycles 2002, 56, 433. (j) Hayashi, K.; Sato, C.; Hiki, S.; Kumagai, T.; Tamai, S.; Abe, T.; Nagao, Y. Tetrahedron Lett. 1999, 40, 3761. (k) Bartnik, R.; Marchand, A. P. Synlett 1997, 1029. (1) Dejaegher, Y.; Mangelinckx, S.; De Kimpe, N. J. Org. Chem. 2002, 67, 2075. (m) Van Brabandt, W.; Van Landeghem, R.; De Kimpe, N. Org. Lett. 2006, 8, 1105. (n) Sulmon, P.; De Kimpe, N.; Schamp, N.; Tinant, B.; Declercq, J.-P. Tetrahedron 1988, 44, 3653. (o) De Kimpe, N.; De Smaele, D. Tetrahedron Lett. 1994, 35, 8023. (p) Dejaegher, Y.; De Kimpe, N. J. Org. Chem. 2004, 69, 5974. (q) Van Brabandt, W.; Dejaegher, Y.; Van Landeghem, R.; De Kimpe, N. Org. Lett. 2006, 8, 1101. (r) Van Driessche, B.; Van Brabandt, W.; D'hooghe, M.; Dejaegher, Y.; De Kimpe, N. Tetrahedron 2006, 62, 6882. (s) Salgado, A.; Dejaegher, Y.; Verniest, G.; Boeykens, M.; Gauthier, C.; Lopin, C.; Abbaspour Tehrani, K.; De Kimpe, N. Tetrahedron 2003, 59, 2231.

(4) (a) Cromwell, N. H.; Phillips, B. Chem. Rev. 1979, 79, 331. (b) Moore, J. A.; Ayers, R. S. Chemistry of Heterocyclic CompoundsSmall Ring Heterocycles; Hassner, A., Ed.; Wiley: New York, 1983; Part 2, pp 1-217. (c) Davies, D. E.; Storr, R. C. Comprehensive Heterocyclic Chemistry; Lwowski, W., Ed.; Pergamon: Oxford, 1984; Vol. 7, Part 5, pp 237-284. (d) Singh, G. S.; D'hooghe, M.; De Kimpe, N. Azetidines, Azetines, and Azetes: Monocyclic. In Comprehensive Heterocyclic Chemistry III, a review of the literature 1995-2007; Katritzky, A., Ramsden, C., Scriven, E., Taylor, R., Eds.; Elsevier: Oxford, 2008; Vol. 2, pp 1-110.

(5) Fyfe, M. C. T.; Gattrell, W.; Rasamison, C. M. PCT Int. Appl. 2007, WO 2007116230 Al; Chem. Abstr. 2007, 147, 469218.

(6) Isabel, E.; Oballa, R.; Powell, D.; Robichaud, J. PCT Int. Appl. 2007, WO $2007143823 \mathrm{Al}$; Chem. Abstr. 2007, 148, 78872.

(7) Josyula, V. P. V. N.; Renslo, A. R. PCT Int. Appl. 2007, WO $2007004049 \mathrm{Al}$; Chem. Abstr. 2007, 146, 142631.

(8) (a) Vervisch, K.; D’hooghe, M.; Törnroos, K. W.; De Kimpe, N. Org. Biomol. Chem. 2009, 7, 3271. (b) D'hooghe, M.; Vervisch, K.; Törnroos, K. W; De Kimpe, N. J. Org. Chem. 2007, 72, 7329.

(9) D’hooghe, M.; Vanlangendonck, T.; Törnroos, K. W.; De Kimpe, N. J. Org. Chem. 2006, 71, 4678.

(10) (a) De Smaele, D.; Bogaert, P.; De Kimpe, N. Tetrahedron Lett. 1998, 39, 9797. (b) D'hooghe, M.; Van Nieuwenhove, A.; Van Brabandt, W.; Rottiers, M.; De Kimpe, N. Tetrahedron 2008, 64, 1064. (11) D’hooghe, M.; Waterinckx, A.; De Kimpe, N. J. Org. Chem. 2005, 70, 227.
(12) Vervisch, K.; D’hooghe, M.; Törnroos, K. W.; De Kimpe, N. J. Org. Chem. 2010, 75, 7734.

(13) (a) Sheikha, G. A.; La Colla, P.; Loi, A. G. Nucleos. Nucleot. Nucl. 2002, 21, 619. (b) D’hooghe, M.; Kenis, S.; Vervisch, K.; Lategan, C.; Smith, P. J.; Chibale, K.; De Kimpe, N. Eur. J. Med. Chem. 2011, 46, 579. (c) D'hooghe, M.; De Kimpe, N. Chem. Commun. 2007, 1275.

(14) (a) D’hooghe, M.; Mangelinckx, S.; Persyn, E.; Van Brabandt, W.; De Kimpe, N. J. Org. Chem. 2006, 71, 4232. (b) D’hooghe, M.; Rottiers, M.; Jolie, R.; De Kimpe, N. Synlett 2005, 931.

(15) (a) De Kimpe, N.; Jolie, R.; De Smaele, D. J. Chem. Soc. Chem. Commun. 1994, 1221. (b) De Kimpe, N.; De Smaele, D.; Szakonyi, Z. J. Org. Chem. 1997, 62, 2448.

(16) Stanković, S.; Catak, S.; D’hooghe, M.; Goossens, H.; Abbaspour Tehrani, K.; Bogaert, P.; Waroquier, M.; Van Speybroeck, V.; De Kimpe, N. J. Org. Chem. 2011, 76, 2157.

(17) (a) Mangelinckx, S.; Žukauskaitè, A.; Buinauskaitè, V.; Šačkus, A.; De Kimpe, N. Tetrahedron Lett. 2008, 49, 6896. (b) Žukauskaite, A.; Mangelinckx, S.; Buinauskaitè, V.; Šačkus, A.; De Kimpe, N. Amino Acids 2011, 41, 541. (c) Gaertner, V. R. J. Org. Chem. 1970, 35, 3952.

(18) (a) Van Brabandt, W.; Mangelinckx, S.; D'hooghe, M.; Van Driessche, B.; De Kimpe, N. Curr. Org. Chem. 2009, 13, 829. (b) Stanković, S.; D’hooghe, M.; Abbaspour Tehrani, K.; De Kimpe, N. Tetrahedron Lett. 2012, 53, 107.

(19) Okutani, T.; Masuda, K. Chem. Pharm. Bull. 1974, 22, 1498.

(20) Miller, J.; Parker, A. J. J. Am. Chem. Soc. 1961, 83, 117.

(21) (a) Böes, E. S.; Livotto, P. R.; Stassen, H. Chem. Phys. 2006, 331, 142. (b) Marcus, Y. Pure Appl. Chem. 1983, 55, 977. (c) Marcus, Y. Pure Appl. Chem. 1985, 57, 1103. (d) Pliego, J. R. Jr; Riveros, J. M. Phys. Chem. Chem. Phys. 2002, 4, 1622. (e) Marcus, Y. Biophys. Chem. 1994, 51, 2995.

(22) (a) Lee, C. T.; Yang, W. T.; Parr, R. G. Phys. Rev. B 1988, 37, 785. (b) Becke, A. D. J. Chem. Phys. 1993, 98, 5648.

(23) Izgorodina, E. I.; Coote, M. L. Chem. Phys. 2006, 324, 96.

(24) (a) Lynch, B. J.; Fast, P. L.; Harris, M.; Truhlar, D. G. J. Phys. Chem. A 2000, 104, 4811. (b) Lynch, B. J.; Zhao, Y.; Truhlar, D. G. J. Phys. Chem. A 2003, 107, 1384. (c) Vansteenkiste, P.; Van Speybroeck, V.; Verniest, G.; De Kimpe, N.; Waroquier, M. J. Phys. Chem. A 2006, 110, 3838. (d) Van Cauter, K.; Van Speybroeck, V.; Waroquier, M. Chem. Phys. Chem. 2007, 8, 541. (e) Hermosilla, L.; Catak, S.; Van Speybroeck, V.; Waroquier, M.; Vandenbergh, J.; Motmans, F.; Adriaensens, P.; Lutsen, L.; Cleij, T.; Vanderzande, D. Macromolecules 2010, 43, 7424. (f) Goossens, H.; Vervisch, K.; Catak, S.; Stanković, S.; D'hooghe, M.; De Proft, F.; Geerlings, P.; De Kimpe, N.; Waroquier, M.; Van Speybroeck, V. J. Org. Chem. 2011, 76, 8698.

(25) (a) Bauschlicher, C. W.; Partridge, H. Chem. Phys. Lett. 1995, 240, 533. (b) Bell, R. D.; Wilson, A. K. Chem. Phys. Lett. 2004, 394, 105. (c) Yockel, S.; Wilson, A. K. Chem. Phys. Lett. 2006, 429, 645.

(26) Frisch, M. J. et al. Gaussian 09, Revision A.02; Gaussian, Inc.: Wallingford, CT, 2009.

(27) (a) D'hooghe, M.; Van Speybroeck, V.; Van Nieuwenhove, A.; Waroquier, M.; De Kimpe, N. J. Org. Chem. 2007, 72, 4733. (b) Catak, S.; D’hooghe, M.; De Kimpe, N.; Waroquier, M.; Van Speybroeck, V. J. Org. Chem. 2010, 75, 885. (c) Catak, S.; D’hooghe, M.; Verstraelen, T.; Hemelsoet, K.; Van Nieuwenhove, A.; Ha, H.-J.; Waroquier, M.; De Kimpe, N.; Van Speybroeck, V. J. Org. Chem. 2010, 75, 4530. 